\title{
California's Commercial Fisheries: 1981-2012
}

\author{
CYNTHIA J. THOMSON
}

\section{Introduction}

The 1976 Magnuson-Stevens Fishery Conservation and Management Act (MSFCMA, 1976) extended U.S. authority to $200 \mathrm{nmi}$ (later named the Exclusive Economic Zone), instituted regional fishery management councils to develop and implement fishery management plans, provided national standards for those plans, and restricted foreign fishing in U.S. waters. Management priorities have shifted since the 1970's from removing foreign fleets (French et al., 1981) and encouraging domestic fishery development in the U.S. EEZ (Mansfield, 2001) to addressing overfishing and overcapitalization in domestic fisheries.

Thus the MSFCMA has been subject to two major amendments. The 1996 amendment, known as the Sustainable Fisheries Act (MSFCMA, 1996), includes provisions to prevent overfishing and rebuild overfished stocks, consider potential effects of management measures on fishing communities, minimize bycatch and bycatch mortality, and specify essential fish habitat in fishery management

Cynthia J. Thomson is with the Fisheries Ecology Division, Southwest Fisheries Science Center, National Marine Fisheries Service, NOAA, 110 Shaffer Road, Santa Cruz, CA 95060.

doi: dx.doi.org/10.7755/MFR.77.3.5 plans. The 2006 amendment, known as the Magnuson-Stevens Fishery Conservation and Management Reauthorization Act (MSFCMA, 2007), includes annual catch limits and accountability measures to strengthen the provisions to end overfishing, and established conditions for implementation of catch share programs.

The Pacific Fishery Management Council (PFMC), one of the regional councils established by the MSFCMA, implemented a Pacific Salmon Fishery Management Plan (FMP) in 1977 (PFMC, 1977), a Northern Anchovy FMP in 1978 (PFMC, 1978), a Pacific Groundfish FMP in 1982 (PFMC, 1984), a Coastal Pelagic Species FMP (PFMC, 1998a) that superseded the Northern Anchovy FMP, a Highly Migratory Species FMP in 2004 (PFMC, 2003), and a Fishery Ecosystem Plan in 2013 (DeReynier, 2012; PFMC, 2013a). The MSFCMA - as well as mandates such as the Endangered Species Act (ESA) - have led to a greater focus on reducing fishery impacts not only on target species but also on other components of the ecosystem, i.e., nontarget (bycatch) species and habitat.

For instance, PFMC groundfish management includes a complex mix of harvest, effort, area, season, and gear regulations that constrain target species catches (in some cases to lev- els well below maximum sustainable yield) to minimize bycatch of overfished stocks that comingle with targeted stocks on the fishing grounds (Hilborn et al., 2011; Melnychuk et al., 2013). The PFMC has also implemented habitat protection measures, including closure of essential fish habitat to trawling (PFMC, 1998b).

PFMC management of the Pacific salmon, Oncorhynchus spp., fishery is similarly driven by the need to restrict the level, location, and timing of harvest of more abundant stocks to minimize bycatch of "weak" stocks (including ESA-listed salmonids) that co-mingle with these more abundant stocks in the ocean fishery (Satterthwaite, 2014). Other examples of bycatch concerns addressed by the PFMC include restrictions on salmon bycatch by Pacific whiting, Merluccius productus, trawlers (PFMC, 1997), groundfish bycatch by shrimp, Pandalus jordani, trawlers (Hannah and Jones, 2007), and sea turtle, Dermochelys coriacea, Caretta caretta, Chelonia mydas, and Lepidochelys olvacea, bycatch by swordfish, Xiphias gladius, pelagic longline and drift gillnet vessels (Caretta et al., 2004; PFMC, 2013b). In 2008 the PFMC added krill, Euphausiacea, to the Coastal Pelagic Species FMP and placed a ban on harvest of these important forage species (PFMC, 2008b).
ABSTRACT-This paper discusses the diverse and dynamic nature of California's commercial fisheries and the resource, environmental, economic, and regulatory factors that affected participation, landings, and ex-vessel revenues during 1981-2012. Fishery trends are a simplistic and some- times misleading basis for judging management performance, as increasing and decreasing trends can occur for a variety of reasons. An important management responsibility is to ensure that harvest restrictions are responsive to stock dynamics, regardless of their cause. I highlight a number of socioeconomic characteristics (e.g., the positive effect of fishery diversification and geographic mobility on vessel revenues, the high proportion of vessels that land exclusively in one port, the patterns of movement among fisheries) that should be considered in management decision making. 
Fishery management has changed at the state level as well. In 1998 the State of California enacted the Marine Life Management Act (MLMA, 1998), which expanded the focus of state management to include not just exploited marine populations but marine wildlife and marine habitat in general. The MLMA includes some provisions that are similar to the federal MSFCMA - e.g., rebuilding depressed stocks, reducing bycatch, and considering effects on fishing communities.

One important outcome of the MLMA was development of the State Nearshore Finfish Management Plan (NFMP) in 2002 (CDFG, 2002). The 19 species included in the NFMP overlap with some of the species in the PFMC's Groundfish FMP; the two plans complement and enhance protection of these overlapping species. In 1999 the state enacted the Marine Life Protection Act (MLPA, 1999), which mandated the establishment of a system of marine protected areas (MPA's). During 2007-12, MPA's were implemented in four designated regions encompassing the California coast; MPA's for the fifth region (San Francisco Bay) will be considered at a future date (Saarman and Carr, 2013).

This paper provides a retrospective view of California commercial fisheries over the past three decades. ${ }^{1}$ Changes in management strategies, such as those cited above, have influenced fishery trends. However, some caution is warranted in interpreting these trends, as the effectiveness of current management cannot be determined solely on the basis of whether a trend is up or down. Declining harvests may be indicative of poor or nonexistent management, but they can also occur when management is proactive and responsive to changes in stock abundance. Managers cannot be expected to sustain the harvest levels achieved in a developing fishery, as

${ }^{1}$ See McEvoy (1986) and Mason (2004) for insightful perspectives on long-term trends in California fisheries. See Leet et al. (2001) for detailed, species-specific descriptions of California landings trends, population status, and fishery management prior to 2000 . the dynamics of exploited fish stocks make harvest reductions inevitable, even in well-managed fisheries.

Management should be considered in the context of other factors that also affect fishery trends. Environmental conditions (e.g., El Niño/Southern Oscillation, Pacific Decadal Oscillation, climate change) can have shortto long-term effects on the abundance and distribution of target and bycatch species (MacCall, 1996; Mantua et al., 1997; Lindegren and Checkley, 2013). Economic factors (e.g., domestic and global seafood demand, conditions in other U.S. and foreign fisheries that supply the same markets as California fisheries, ex-vessel prices, fishing costs) can influence the development and decline of fisheries and the amount of pressure exerted on particular stocks (Vojkovich, 1998; Herrick et al., 2006; Knapp et al., 2007; Anderson et al., 2011).

Technological change can also affect harvest opportunities. For instance, fish finding and harvesting technology can improve harvest efficiency (although competitive advantage may be diminished to the extent that adoption of such methods becomes widespread); changes of this type have led to standardization of effort in stock assessments to avoid confounding the effects of fishing power and stock abundance on CPUE (Maunder and Punt, 2004). Technology also includes methods to reduce take of nontarget species (e.g., bycatch reduction devices) and discourage fishing in certain habitats (e.g., use of small footropes to discourage trawling in rocky habitat). Life history characteristics of target and bycatch species and other biological traits, such as habitat preferences and schooling behavior, can affect their vulnerability to fishing and their ability to recover from overfishing and environmental adversity.

Stock assessments reflect the biology of the species and the influence of historical catches and environmental conditions on current abundance (Methot et al., 2013). Harvest control rules adopted by the PFMC ensure that the outcome of stock assessments are reflected in annual catch limits (ACL's). Catches, in turn, affect future stock trajectories.

Stocks are typically assessed throughout their geographic range. Harvest control rules likewise are used to establish ACL's for entire stocks which can be suballocated among fishery sectors and geographic areas. Catches by any particular sector (e.g., California commercial) may or may not be correlated with stock abundance, depending on factors such as the distribution of the fishery relative to the distribution of the stock. Weak-stock management policies constrain target species harvests (often below levels warranted solely by target species abundance) to achieve desired reductions in bycatch of weak stocks. Inferences regarding abundance from harvest trends should be made with such factors in mind.

This paper describes California fishery trends in terms of three indicators: vessel participation, landings, and exvessel revenue. As will be seen, these indicators do not necessarily follow similar patterns for a given fishery, and they can also differ depending on the temporal and geographic scale at which they are depicted. Different indicators and scales provide different insights into fisheries and underscore the need for nuanced interpretation of the data. California fisheries are diverse, not just in terms of species, gear type, fishing strategies, location, and trends, but also in terms of the factors that influence those trends.

The section on California landings during 1916-2012 focuses on trends in several historically significant fisheries. Later sections provide a more detailed description of fishery trends in the recent decades, 1981-2012, as summarized from vessel-level landings receipts data that have been available in electronic form since 1981. Specifically, information is provided on statewide trends in individual fisheries in terms of participation, landings, and ex-vessel revenues. Also, more geographic specificity is given by describing overall fishery trends by region and port and highlighting fisheries that are particularly influential in 


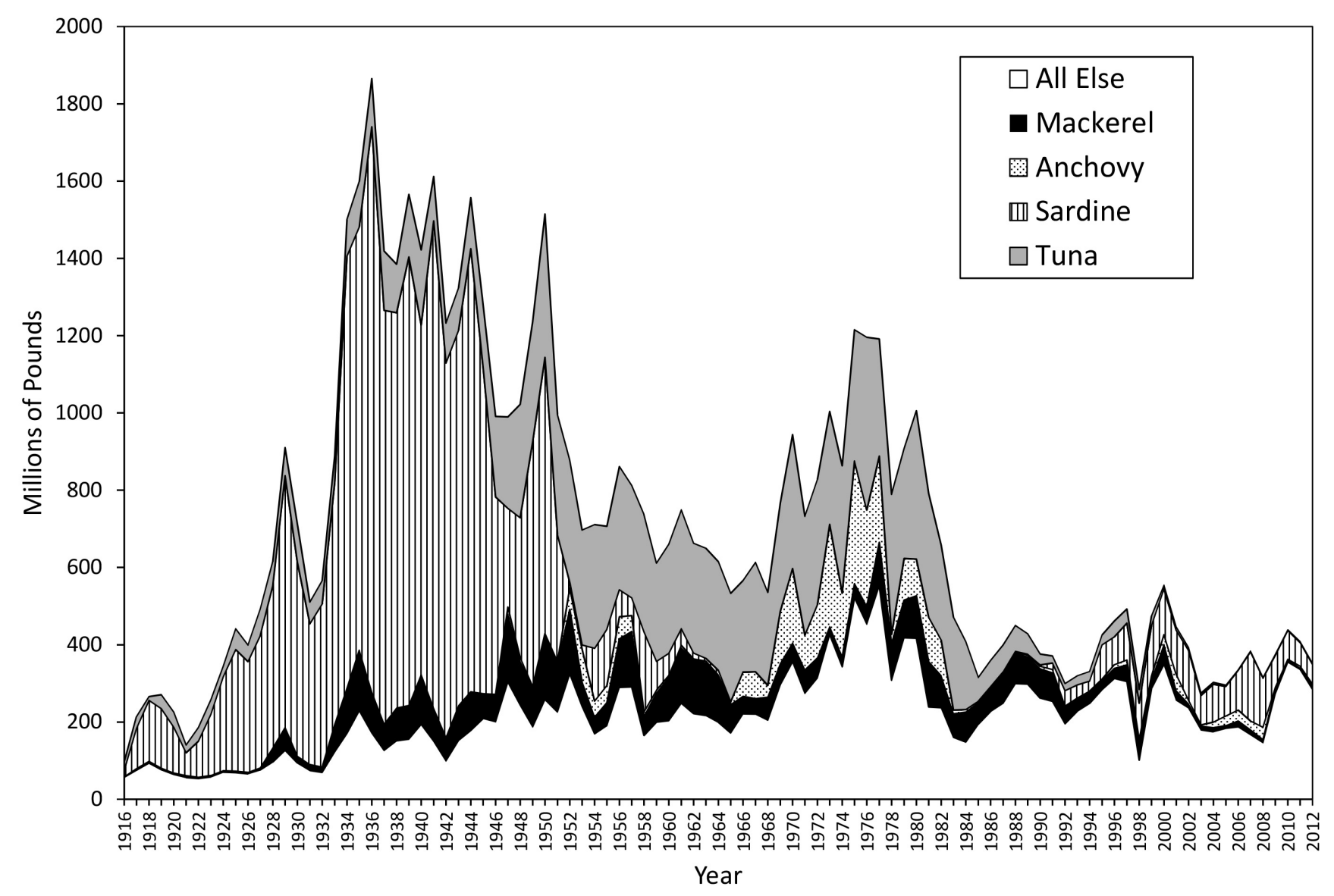

Figure 1.-California commercial landings, 1916-2012 (sources: Leet et al., 2001 and PacFIN).

each geographic area. Finally, vessel behavior is described as it relates to revenues, fishery diversification, and geographic mobility. Then conclusions are drawn from analyses contained in the previous sections.

All landings volumes are reported here in landed weight and all dollar values are corrected for inflation to base year 2012. Trips are assigned to fisheries based on the species/gear combination accounting for the plurality of revenue earned on the trip. A vessel that made at least one trip in a given fishery is designated a participant in that fishery.

\section{California Commercial Fishery Trends 1916-2012}

Figure 1 provides a historical perspective on California commercial landings since 1916. Notable landings peaks occurred during 1934-48
(1.2-1.8 billion $\mathrm{lb}), 1949-50$ (1.1-1.3 billion lb), and 1975-77 (856-901 million $\mathrm{lb}$ ). The major contributor to the first two peaks was the Pacific sardine, Sardinops sagax, fishery, while tuna, Thunnus spp., and northern anchovy, Engraulis mordax, were major contributors to the third peak.

Landings of coastal pelagic speciesPacific sardine; northern anchovy; Pacific mackerel, Scomber japonicas; and jack mackerel, Trachurus symmetricus - have varied widely in both absolute and relative terms since 1916. Demand for canned sardines developed during World War I and was soon overshadowed by the more lucrative market for fish meal and oil, which were produced from cannery waste by a process known as reduction. California processors operated reduction plants in conjunction with canneries, then further augmented meal and oil production by using whole fish for reduction. During 1920-41, concerns expressed by CDFG and federal biologists led to passage of various state laws intended to reserve use of sardines for human consumption. Processors circumvented these laws by harvesting and reducing sardines outside the state's 3-mile jurisdiction, a situation that continued until 1938, when fish meal and oil prices fell and an amendment to the California Constitution gave the state the authority to stop offshore reduction (Ueber and MacCall, 1992). During the 1930's and 1940's, the sardine stock (which expands its range as abundance increases) supported high-volume fisheries from Mexico to British Columbia (Radovich, 1982). Sardines comprised $44-62 \%$ of total California landings during $1917-23$ and $70-83 \%$ in $1924-$ 45. California sardine landings rou- 
tinely exceeded 900 million $\mathrm{lb}$ during 1934-44, peaking at 1.5 billion $\mathrm{lb}$ in 1936.

The collapse of the California fishery in the 1950's (preceded by collapse of the British Columbia, Washington, and Oregon fisheries in the 1940's) has been attributed to a combination of overfishing and adverse environmental conditions (Marr, 1960; McEvoy, 1986; Ueber and MacCall, 1992). The State of California imposed a moratorium on directed sardine landings in 1974 which was lifted in 1986 (Wolf, 1992) under a harvest regime that continued in similar form when a federal Coastal Pelagics Species (CPS) Fishery Management Plan that included sardine was implemented in 2000 (PFMC, 1998a).

The collapse of the sardine fishery in the 1950's was followed by development of the northern anchovy reduction fishery in 1966, which peaked at 317 million $\mathrm{lb}$ in 1975 and ceased operation by the late 1980 's, when record low reduction prices made the fishery unviable (CDFG, 1990:13-14). CPS landings were subsequently dominated by mackerel until the mid-1990's, when the sardine stock had recovered sufficiently to support a substantial fishery. Since then, sardine landings reached a high of 179 million $\mathrm{lb}$ in 2007-a substantial volume but well below the amounts harvested in the heyday of the fishery. Sardines are now marketed for non-reduction uses, including human consumption, aquaculture feed, and bait in recreational and commercial fisheries (Herrick et al., 2006).

The tuna fishery expanded as demand for canned tuna increased after World War II. Tuna landings increased from 10-99 million lb during 1916-33 to 94-194 million $\mathrm{lb}$ during 1934-45, and peaked at 176-384 million lb during 1946-83 (except for the record 1976 year, when harvest reached 447 million $\mathrm{lb}$ ). Landings subsequently declined to 176 million $\mathrm{lb}$ in 1984 to an average of 64 million $\mathrm{lb}$ during 198589, 28 million $\mathrm{lb}$ during 1990-99, and 4 million $\mathrm{lb}$ during 2000-12. Tunas comprised $23-62 \%$ of total California landings during the peak years 194683 , but less than $2 \%$ during 2000-12. Tuna harvests included troll landings of premium "white meat" albacore tuna, Thunnus alalunga, and highervolume landings of yellowfin, T. albacares, and skipjack, Katsuwonus pelamis, by tuna clipper "baitboats" and later seiners. Albacore constituted the plurality if not majority of California tuna landings during 1916-25 and 1999-2012, while yellowfin constituted the plurality/majority for 67 of the 73 years 1926-98 (skipjack being the plurality/majority in the remaining 6 years).

Until the late 1950's, yellowfin and skipjack tunas were targeted by baitboat fishermen who used chum to attract tunas and employed poles with short lines and barbless hooks to heave the fish over their shoulders onto the deck (Godsil, 1938). Improved refrigeration methods in the 1930's enabled these boats to extend their range farther south and offshore. By the late 1950's, technological improvements (nylon nets, Puretic powerblock ${ }^{2}$ ) led to development of the tuna purse seine fishery.

California seiners were of two distinctive types. One fleet consisted of smaller "wetfish" boats (25-150 short tons capacity), based in the San Pedro area, that targeted CPS finfishes, market squid, Loligo opalescens, and also tunas in years when they appeared in coastal waters of the Southern California Bight (Perrin and Noetzel, 1970). In addition to newer boats, the wetfish fleet also included seiners that had participated in the sardine fishery before its collapse (Knaggs, 1973). The second fleet consisted of large "superseiners" (200-2,000 short ton capacity) that made long-range trips to the eastern Pacific Ocean to harvest tropical tunas, such as yellowfin and skipjack (Orbach, 1977; Rockland, 1978). This fleet included baitboats that had been converted to purse seiners as well as newly built seiners. The rapid expansion of this long-range fleet was

${ }^{2}$ Mention of trade names and commercial firms does not imply endorsement by the National Marine Fisheries Service, NOAA facilitated by federal programs that encouraged capitalization and investment in fisheries. ${ }^{3}$

The Inter-American Tropical Tuna Commission manages yellowfin tuna within the Commission's Yellowfin Regulatory Area (CYRA). Concerns regarding incidental mortality of pantropical spotted, Stenella attenuata; spinner, S. longirostris; and common, Delphinus delphis, dolphins by seiners in the CYRA in the late 1960's prompted technological changes that reduced dolphin mortality by U.S. seiners to minimal levels by the early 1980's (Coe et al., 1984). Landings by the high-seas fleet in California also plummeted by the early 1980's as tax advantages and lower costs caused tuna canneries to close their operations in southern California in favor of Puerto Rico and American Samoa (Francis et al., 1992). ${ }^{4}$ The last tuna

${ }^{3}$ Federal support for capitalization and modernization of fishing fleets has taken the form of programs such as the Fisheries Loan Fund (FLF, 1957-73), the Fishing Vessel Mortgage Insurance Program (1962-72), the Fishing Vessel Obligation Guarantee Program (FVOG, 1973-98), the Fisheries Finance Program (1998 to present, including new authority to finance buyback programs and purchase of catch shares by smallscale fishermen and crew members), and the Capital Construction Fund (1970-present). The terms of these programs are specified in legislation such as the 1956 Fish and Wildlife Act, the 1972 Federal Ship Financing Act, and the 1996 Sustainable Fisheries Act as amendments to the 1936 Merchant Marine Act, and reflect the federal government's broader agenda regarding development of the shipping industry. These programs were implemented by the Department of the Interior's Bureau of Commercial Fisheries (BCF) until 1970, when the functions of the $\mathrm{BCF}$ were transferred to the newly-established National Marine Fisheries Service (NMFS). During the late 1950's and early 1960's the BCF issued FLF loans for conversion of 30 baitboats to purse seiners (an additional 70 boats were converted using private funds). Although the FVOG program has experienced very low default rates, a notable exception occurred in 1996, when NMFS seized and auctioned 6 superseiners (all owned by the same family) for $\$ 26.2$ million after low yellowfin prices prompted the family to default on \$21 million in loans they had received in the late 1980's and early 1990's. In 1996, NMFS administratively banned the use of FVOG funds for new vessel construction or for refurbishment of existing vessels that materially increased the vessel's harvesting capacity (FFITF, 1999)

${ }^{4}$ During the 1970's, the U.S. distant-water tuna fleet operated principally in the Eastern Tropical Pacific and landed their catch at canneries in California and Puerto Rico; many of these vessels were owned by U.S. processors. In the late 
cannery in southern California closed in 2001 (PFMC, 2016b). Since then, the relatively modest amounts of tuna still landed in California have been exported overseas for processing.

\section{California Fishery Trends 1981-2012}

This section provides a post-1980 overview of California's commercial fisheries. The information provided here illustrates the diverse and dynamic nature of fishing activity, the varying insights that can be gained by considering fisheries at differing spatial and temporal scales, and the resource, environmental, regulatory, and socioeconomic factors affecting fishery trends. Because vessel behavior, fishery regulations, and ecosystem effects are typically differentiated by gear as well as species, fisheries are depicted here in terms of species/gear combinations.

Table 1 summarizes landings, revenues, and vessel participation trends in the 27 California fisheries that generated at least $\$ 400,000$ in average annual ex-vessel revenue during 19812012. Participation tends to be highest in line and pot fisheries, and landings volume highest in net (seine and trawl) fisheries. Ex-vessel revenue does not necessarily correlate with landings, as

1970's, some Latin American countries established 200-mile exclusive economic zones and expanded their own fleets, prompting U.S. processors to increase their purchases of cheaper, raw tuna from foreign sources. The U.S. fleet declined from 101 to 66 active vessels from 1979 to 1988 , with many of these boats transferring to foreign registry. As indicated by Sakagawa (1991), these transfers were due to prevailing economic conditions (low ex-vessel yellowfin prices, debt service, interest by foreign entities in purchasing U.S. vessels) rather than U.S. tuna-dolphin regulations. Although the dolphin quota became more constraining during this period (declining from 78,000 animals in 1976 to 20,500 animals in 1981 and thereafter), the U.S. fleet stayed within the quota in all but two years (1976 and 1982). U.S. processors closed most of their canneries in southern California and Hawaii during 1979-85 and expanded their operations in American Samoa and Puerto Rico. Canneries in insular territories enjoy economic advantages such as exemption from the Nicholson Act (which prohibits foreign vessels from landing fish taken in high-seas fisheries), dutyfree entry of cannery products into the U.S., and exemption from federal minimum wage standards (Levine and Allen, 2009).
Table 1.-Average annual number of boats, landings (millions of pounds landed weight), and revenue (\$millions, base year=2012) for top-27 California fisheries (based on 1981-2012 average revenue), 1981-2012, by fishery and time interval. Number of boats not additive across fisheries, as some boats participate in multiple fisheries.

\begin{tabular}{|c|c|c|c|c|c|c|c|c|}
\hline & $\begin{array}{c}\text { 1981-2012 } \\
\text { Avg }\end{array}$ & $\begin{array}{c}1981-85 \\
\text { Avg }\end{array}$ & $\begin{array}{c}1986-90 \\
\text { Avg }\end{array}$ & $\begin{array}{c}\text { 1991-95 } \\
\text { Avg }\end{array}$ & $\begin{array}{c}1996-2000 \\
\text { Avg }\end{array}$ & $\begin{array}{c}2001-05 \\
\text { Avg }\end{array}$ & $\begin{array}{c}2006-10 \\
\text { Avg }\end{array}$ & $\begin{array}{c}2011-12 \\
\text { Avg }\end{array}$ \\
\hline \multicolumn{9}{|l|}{ Tuna seine } \\
\hline Boats & 54 & 146 & 71 & 50 & 52 & 19 & 5 & 9 \\
\hline Landings & 42.4 & 184.5 & 49.0 & 15.7 & 19.6 & 2.0 & 0.4 & 0.2 \\
\hline Revenue & 39.9 & 189.7 & 43.7 & 9.3 & 11.5 & 1.0 & 0.2 & 0.3 \\
\hline \multicolumn{9}{|c|}{ Dungeness crab pot } \\
\hline Boats & 541 & 630 & 639 & 655 & 501 & 425 & 424 & 463 \\
\hline Landings & 11.9 & 6.8 & 8.3 & 9.4 & 9.6 & 13.9 & 16.6 & 23.2 \\
\hline Revenue & 26.7 & 17.0 & 20.2 & 18.7 & 23.4 & 28.4 & 35.8 & 69.1 \\
\hline \multicolumn{9}{|l|}{ Squid seine } \\
\hline Boats & 93 & 88 & 84 & 77 & 115 & 98 & 91 & 113 \\
\hline Landings & 114.5 & 23.0 & 65.1 & 96.2 & 160.7 & 132.3 & 159.0 & 241.6 \\
\hline Revenue & 24.6 & 5.6 & 9.6 & 16.0 & 28.1 & 27.1 & 44.7 & 65.9 \\
\hline \multicolumn{9}{|c|}{ Non-whiting groundfish trawl } \\
\hline Boats & 137 & 210 & 194 & 178 & 149 & 88 & 47 & 31 \\
\hline Landings & 38.5 & 75.6 & 60.1 & 44.4 & 33.9 & 15.5 & 13.2 & 9.9 \\
\hline Revenue & 21.8 & 34.7 & 33.5 & 26.7 & 22.0 & 10.4 & 9.1 & 7.2 \\
\hline \multicolumn{9}{|c|}{ Sea urchin dive } \\
\hline Boats & 266 & 223 & 393 & 448 & 283 & 184 & 116 & 133 \\
\hline Landings & 21.6 & 19.5 & 45.4 & 29.6 & 15.6 & 12.4 & 11.1 & 11.5 \\
\hline Revenue & 18.6 & 8.3 & 29.8 & 40.9 & 19.0 & 10.7 & 6.9 & 8.2 \\
\hline \multicolumn{9}{|l|}{ Salmon troll } \\
\hline Boats & 1,378 & 3,220 & 2,429 & 1,241 & 774 & 680 & 258 & 541 \\
\hline Landings & 4.2 & 4.8 & 8.4 & 3.5 & 4.0 & 4.9 & 0.6 & 1.7 \\
\hline Revenue & 16.0 & 24.4 & 37.5 & 11.0 & 9.1 & 13.4 & 3.1 & 9.1 \\
\hline \multicolumn{9}{|l|}{ CPS seine } \\
\hline Boats & 95 & 155 & 134 & 92 & 88 & 65 & 53 & 56 \\
\hline Landings & 130.8 & 167.4 & 129.2 & 85.9 & 153.4 & 130.0 & 144.3 & 67.4 \\
\hline Revenue & 12.6 & 26.3 & 16.7 & 7.9 & 10.3 & 7.5 & 9.4 & 5.5 \\
\hline \multicolumn{9}{|c|}{ Groundfish fixed gear } \\
\hline Boats & 889 & 1,156 & 1,147 & 1,172 & 978 & 564 & 474 & 493 \\
\hline Landings & 6.9 & 10.4 & 9.0 & 9.5 & 6.4 & 3.2 & 3.8 & 4.9 \\
\hline Revenue & 10.2 & 8.6 & 9.2 & 11.8 & 12.0 & 7.8 & 9.9 & 14.6 \\
\hline \multicolumn{9}{|l|}{ Albacore troll } \\
\hline Boats & 354 & 996 & 229 & 173 & 414 & 276 & 113 & 164 \\
\hline Landings & 8.0 & 22.9 & 6.6 & 6.4 & 9.8 & 4.0 & 1.1 & 1.4 \\
\hline Revenue & 9.2 & 27.9 & 6.5 & 6.9 & 10.8 & 3.9 & 1.5 & 2.6 \\
\hline \multicolumn{9}{|l|}{ Herring net } \\
\hline Boats & 192 & 392 & 350 & 205 & 156 & 88 & 28 & 27 \\
\hline Landings & 9.8 & 16.0 & 18.3 & 11.4 & 10.1 & 4.4 & 1.2 & 3.4 \\
\hline Revenue & 7.4 & 14.4 & 10.5 & 10.1 & 9.8 & 2.0 & 0.4 & 0.6 \\
\hline \multicolumn{9}{|c|}{ Swordfish net } \\
\hline Boats & 102 & 184 & 171 & 120 & 93 & 44 & 33 & 18 \\
\hline Landings & 1.4 & 2.7 & 2.3 & 1.6 & 1.1 & 0.4 & 0.5 & 0.2 \\
\hline Revenue & 7.0 & 13.8 & 14.6 & 8.5 & 4.5 & 1.6 & 1.7 & 0.8 \\
\hline \multicolumn{9}{|l|}{ Lobster pot } \\
\hline Boats & 204 & 235 & 223 & 247 & 202 & 164 & 163 & 180 \\
\hline Landings & 0.6 & 0.5 & 0.6 & 0.6 & 0.7 & 0.8 & 0.7 & 0.8 \\
\hline Revenue & 6.6 & 3.7 & 5.3 & 5.7 & 6.7 & 6.5 & 9.1 & 13.5 \\
\hline \multicolumn{9}{|c|}{ Pink shrimp trawl } \\
\hline Boats & 52 & 56 & 72 & 94 & 80 & 18 & 7 & 12 \\
\hline Landings & 5.8 & 3.0 & 9.6 & 10.9 & 6.4 & 2.8 & 1.9 & 6.8 \\
\hline Revenue & 4.0 & 3.0 & 7.9 & 7.5 & 4.1 & 1.2 & 0.7 & 3.3 \\
\hline
\end{tabular}

revenue depends on ex-vessel price as well as volume landed.

\section{Fishery Participation}

The number of boats participating in California fisheries declined from 6,892 in 1981 to 1,479 in 2009 , then increased to 1,877 by 2012 . Participation trends are driven largely by three fisheries: Pacific salmon troll, groundfish fixed gear, and Dungeness crab, Cancer magister (Fig. 2). Due to the sheer number of salmon trollers, the salmon fishery has tended to drive the overall statewide pattern of vessel participation. Participation in the groundfish fixed gear and Dungeness crab fisheries has also been substantial but more stable than salmon participation.

\section{Salmon Troll}

The salmon troll fishery, one of the oldest fisheries in California, expanded during World War II (Fig. 3), encouraged by favorable market conditions, modest capital requirements for vessel entry, and lack of regulatory controls on entry. By the 1980's, however, participation was on a downward trend, declining from 4,155 boats in 1981 to 2,094 boats in 1990 , then 
Table 1.-Continued

\begin{tabular}{|c|c|c|c|c|c|c|c|c|}
\hline & $\begin{array}{c}1981-2012 \\
\text { Avg }\end{array}$ & $\begin{array}{c}1981-85 \\
\text { Avg }\end{array}$ & $\begin{array}{c}1986-90 \\
\text { Avg }\end{array}$ & $\begin{array}{c}1991-95 \\
\text { Avg }\end{array}$ & $\begin{array}{c}1996-2000 \\
\text { Avg }\end{array}$ & $\begin{array}{c}2001-05 \\
\text { Avg }\end{array}$ & $\begin{array}{c}2006-10 \\
\text { Avg }\end{array}$ & $\begin{array}{c}2011-12 \\
\text { Avg }\end{array}$ \\
\hline \multicolumn{9}{|c|}{ Swordfish line/harpoon } \\
\hline Boats & 67 & 135 & 88 & 61 & 57 & 47 & 30 & 22 \\
\hline Landings & 0.8 & 0.3 & 0.3 & 0.5 & 1.5 & 1.9 & 0.2 & 0.6 \\
\hline Revenue & 3.1 & 2.0 & 2.3 & 2.9 & 5.5 & 5.8 & 1.0 & 2.0 \\
\hline \multicolumn{9}{|c|}{ Halibut net/trawl } \\
\hline Boats & 159 & 267 & 251 & 154 & 144 & 108 & 70 & 61 \\
\hline Landings & 0.8 & 1.2 & 1.0 & 0.7 & 1.0 & 0.7 & 0.4 & 0.3 \\
\hline Revenue & 2.9 & 3.8 & 3.9 & 2.6 & 3.3 & 2.7 & 1.8 & 1.4 \\
\hline \multicolumn{9}{|l|}{ Abalone dive } \\
\hline Boats & 61 & 139 & 115 & 104 & 29 & 0 & 0 & 0 \\
\hline Landings & 0.3 & 1.0 & 0.6 & 0.4 & 0.1 & 0.0 & 0.0 & 0.0 \\
\hline Revenue & 2.3 & 5.0 & 4.6 & 4.3 & 1.0 & 0.0 & 0.0 & 0.0 \\
\hline \multicolumn{9}{|c|}{ Rock crab pot } \\
\hline Boats & 139 & 142 & 158 & 163 & 156 & 140 & 92 & 101 \\
\hline Landings & 1.4 & 1.4 & 1.7 & 1.4 & 1.2 & 1.4 & 1.3 & 1.7 \\
\hline Revenue & 2.2 & 2.3 & 2.7 & 2.1 & 1.9 & 2.1 & 1.8 & 2.3 \\
\hline \multicolumn{9}{|c|}{ Groundfish net } \\
\hline Boats & 100 & 240 & 238 & 103 & 33 & 15 & 8 & 5 \\
\hline Landings & 2.8 & 6.2 & 8.5 & 2.8 & 0.4 & 0.0 & 0.0 & 0.0 \\
\hline Revenue & 2.0 & 4.3 & 6.0 & 1.9 & 0.3 & 0.0 & 0.0 & 0.0 \\
\hline \multicolumn{9}{|l|}{ Prawn pot } \\
\hline Boats & 38 & 8 & 36 & 58 & 56 & 39 & 32 & 32 \\
\hline Landings & 0.2 & 0.0 & 0.1 & 0.2 & 0.2 & 0.3 & 0.3 & 0.5 \\
\hline Revenue & 2.0 & 0.1 & 0.9 & 1.6 & 2.2 & 2.8 & 3.6 & 4.6 \\
\hline \multicolumn{9}{|l|}{ Prawn trawl } \\
\hline Boats & 34 & 39 & 32 & 38 & 58 & 36 & 12 & 14 \\
\hline Landings & 0.5 & 0.5 & 0.3 & 0.3 & 1.3 & 0.4 & 0.3 & 0.2 \\
\hline Revenue & 1.9 & 1.5 & 0.8 & 1.8 & 5.5 & 1.5 & 0.7 & 0.5 \\
\hline \multicolumn{9}{|l|}{ Shark net } \\
\hline Boats & 142 & 291 & 254 & 138 & 101 & 66 & 46 & 34 \\
\hline Landings & 1.1 & 3.0 & 1.7 & 0.8 & 0.6 & 0.5 & 0.3 & 0.1 \\
\hline Revenue & 1.7 & 4.7 & 2.9 & 1.3 & 1.1 & 0.7 & 0.4 & 0.2 \\
\hline \multicolumn{9}{|c|}{ White seabass net } \\
\hline Boats & 89 & 85 & 80 & 68 & 69 & 91 & 90 & 224 \\
\hline Landings & 0.3 & 0.2 & 0.1 & 0.1 & 0.2 & 0.3 & 0.5 & 0.5 \\
\hline Revenue & 0.7 & 0.8 & 0.4 & 0.3 & 0.4 & 0.8 & 1.3 & 1.5 \\
\hline \multicolumn{9}{|l|}{ Whiting trawl } \\
\hline Boats & 7 & 11 & 9 & 6 & 8 & 4 & 7 & 0 \\
\hline Landings & 7.7 & 3.5 & 11.8 & 10.0 & 9.3 & 6.8 & 7.7 & 0.0 \\
\hline Revenue & 0.6 & 0.5 & 1.3 & 0.8 & 0.6 & 0.4 & 0.6 & 0.0 \\
\hline \multicolumn{9}{|c|}{ Sea cucumber trawl/dive } \\
\hline Boats & 40 & 8 & 11 & 68 & 57 & 49 & 41 & 57 \\
\hline Landings & 0.5 & 0.0 & 0.1 & 0.6 & 0.6 & 0.7 & 0.5 & 0.6 \\
\hline Revenue & 0.6 & 0.0 & 0.0 & 0.5 & 0.6 & 0.7 & 1.0 & 2.6 \\
\hline \multicolumn{9}{|l|}{ Halibut line } \\
\hline Boats & 205 & 104 & 182 & 239 & 253 & 232 & 205 & 244 \\
\hline Landings & 0.1 & 0.0 & 0.1 & 0.1 & 0.2 & 0.2 & 0.1 & 0.1 \\
\hline Revenue & 0.5 & 0.1 & 0.4 & 0.5 & 0.6 & 0.7 & 0.7 & 0.7 \\
\hline \multicolumn{9}{|l|}{ Shrimp pot } \\
\hline Boats & 11 & 2 & 13 & 15 & 14 & 17 & 8 & 9 \\
\hline Landings & 0.7 & 0.0 & 0.5 & 1.3 & 1.4 & 0.8 & 0.3 & 0.3 \\
\hline Revenue & 0.5 & 0.0 & 0.5 & 0.9 & 1.0 & 0.4 & 0.2 & 0.3 \\
\hline \multicolumn{9}{|l|}{ Hagfish pot } \\
\hline Boats & 14 & 0 & 27 & 2 & 1 & 1 & 44 & 27 \\
\hline Landings & 0.6 & 0.0 & 1.6 & 0.1 & 0.0 & 0.0 & 1.3 & 1.1 \\
\hline Revenue & 0.4 & 0.0 & 1.1 & 0.0 & 0.0 & 0.0 & 1.0 & 0.8 \\
\hline
\end{tabular}

falling more abruptly to 610 by 2007 (Fig. 2). Participation was negligible during 2008-10 due to record low escapements and landings, including unprecedented fishery closures in 2008 and 2009 (PFMC, 2008a; Lindley et al., 2009), then increased to 621 boats by 2012 as stocks experienced a modest rebound. The dependence of salmonids on freshwater as well as ocean habitat contributes to the vulnerability of these species in drought-prone California. Salmon trollers comprised $41-61 \%$ of California vessels during
1981-91 and $25-37 \%$ during 19922007 and 2011-12.

Factors contributing to the decline in participation include establishment of a limited entry program in 1983 (Dewees and Weber, 2001), declining ex-vessel prices, and increasingly restrictive management since the early 1990's (including weak-stock management policies). A particularly notable example of the latter is the prohibition on coho, O. kisutch, retention since 1993 to protect endangered Central California Coast coho; this trans- formed California's troll fishery from a two-species fishery to a Chinook, O. tshawytscha-only fishery (PFMC, 2016a).

\section{Groundfish Fixed Gear}

Groundfish fixed gear (hook-andline and pot) vessels target sablefish, Anoplopoma fimbria, as well as rockfish (Sebastes spp.), lingcod, Ophiodon elongatus, and other groundfish species. Average annual prices increased steadily from $\$ 0.82 / \mathrm{lb}$ during $1981-85$ to $\$ 2.98 / 1 b$ by $2011-12$. Despite these price increases, participation declined from 1,367 boats in 1981 to $446-513$ boats since 2004 (Fig. 2). The PFMC implemented a groundfish limited entry program in 1994 that included fixed gear as well as trawl vessels (PFMC, 1992). Other regulations affecting participation include the fixed gear sablefish endorsement (1997) and permit stacking (2001-02) (PFMC, 2014a), as well as more restrictive ACL's to facilitate rebuilding of overfished rockfishes. The State of California responded to the development of a lucrative live-fishery fishery for nearshore rockfishes in the late 1980's by imposing increasingly restrictive harvest limits, MPA's, and a statewide moratorium on entry in 2000 (CDFG, 2002), followed by a restricted access program in $2003\left(\mathrm{CDFG}^{5}\right)$. Regulatory constraints affected landings as well as participation. Fixed gear landings increased fairly steadily from 7.0 million $\mathrm{lb}$ in 1984 to 12.9 million $\mathrm{lb}$ in 1992 but have been on a downward trajectory ever since (4.0 million $\mathrm{lb}$ in 2012).

\section{Dungeness Crab Pot}

Participation in the Dungeness crab fishery declined from 645-814 boats during 1981-94 to 533-612 boats during $1995-99$ to $401-479$ boats during 2000-10, then increased to 466-487 boats during 2011-12 (Fig. 2). The State of California manages the fishery based on "3-S" principles - sex, size, and season. Harvest is limited to male

${ }^{5}$ CDFG. 2007. Groundfish open access permitting. Ver. 27 July 2007,4 p. Available online at $h t$ ttps://nrm.dfg.ca.gov/FileHandler.ashx? DocumentID=33992 


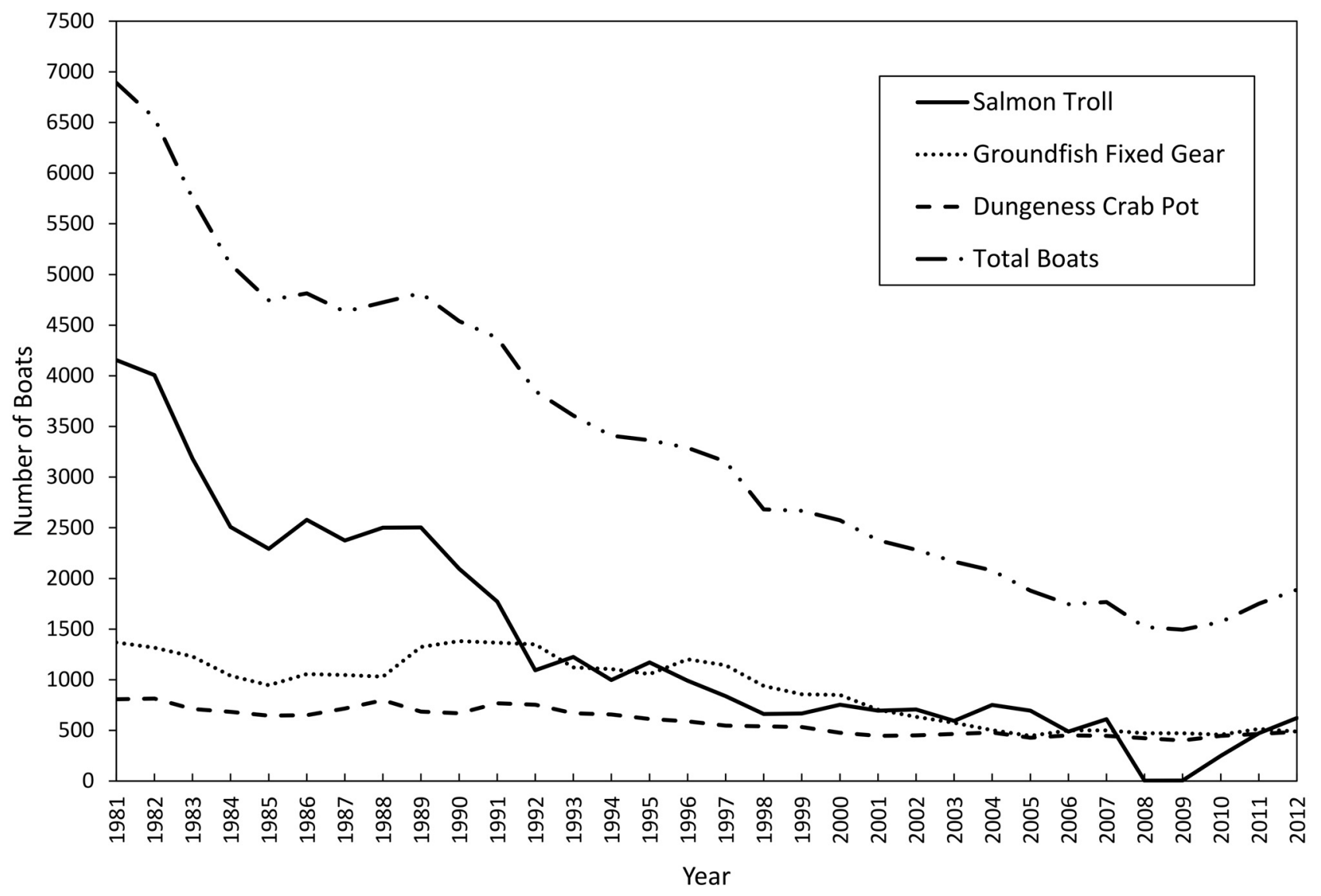

Figure 2.- Total number of boats participating in California commercial fisheries, and number participating in selected fisheries (salmon troll, groundfish fixed gear, Dungeness crab pot), 1981-2012. Boats are not additive across fisheries as some boats participate in multiple fisheries.

crabs that exceed a given size limit, and seasons are imposed to discourage harvest of soft-shelled crabs (Hankin and Warner, 2001). The state established a limited entry program in 1995, and trap limits were implemented beginning in 2013 (CDFG, 2012). Fishery participation is affected by species availability, prices, and (particularly since this is a winter fishery) weather.

\section{Landings}

California landings fell precipitously from 792 million $\mathrm{lb}$ in 1981 to 359 million $\mathrm{lb}$ in 1985 , largely due to the decline in tuna seine landings from 290 to 47 million $\mathrm{lb}$ and the decline in anchovy landings from 115 to 4 million $\mathrm{lb}$. Since 1985, total landings have been variable with no apparent trend. Highs were experienced in 1988 (496 million lb), 1997 (492 million lb), and 2000 (554 million lb); lows were experienced in 1998 (284 million lb) and 2003 (275 million lb) (Fig. 4). Overall landings have trended toward an increase in invertebrate species relative to finfishes. Fisheries that have had the most notable effects on landings are the high-volume seine fisheries for tunas, market squid, and coastal pelagic species (CPS).

\section{Tuna Seine}

Tuna seine landings declined from 290 million lb in 1981 to 47 million $\mathrm{lb}$ in 1985, then stabilized at 46-62 million $\mathrm{lb}$ during 1986-89. Landings continued their downward slide to $12-29$ million $\mathrm{lb}$ in $1990-99$ and 2-5 million $\mathrm{lb}$ in $2000-05$, and have averaged $352,000 \mathrm{lb}$ since 2005 . The precipitous decline in tuna landings that occurred in the early 1980 's is largely due to the overseas relocation of southern California tuna canneries that began in the late 1970's. The last remaining southern California cannery closed in 2001 and most tuna landings are now processed out-of-state (PFMC, 2016b).

\section{Squid Seine}

Unlike the tuna and CPS fisheries - which have a long history of substantial landings in California (Fig. 1) - the fishery for market squid did not experience appreciable growth until the 1980's, when overseas markets in Asia and Europe expanded and U.S. consumers acquired a taste for squid (better known as "calamari"). With the notable exception of 1998 (a lowlandings year with record high prices 


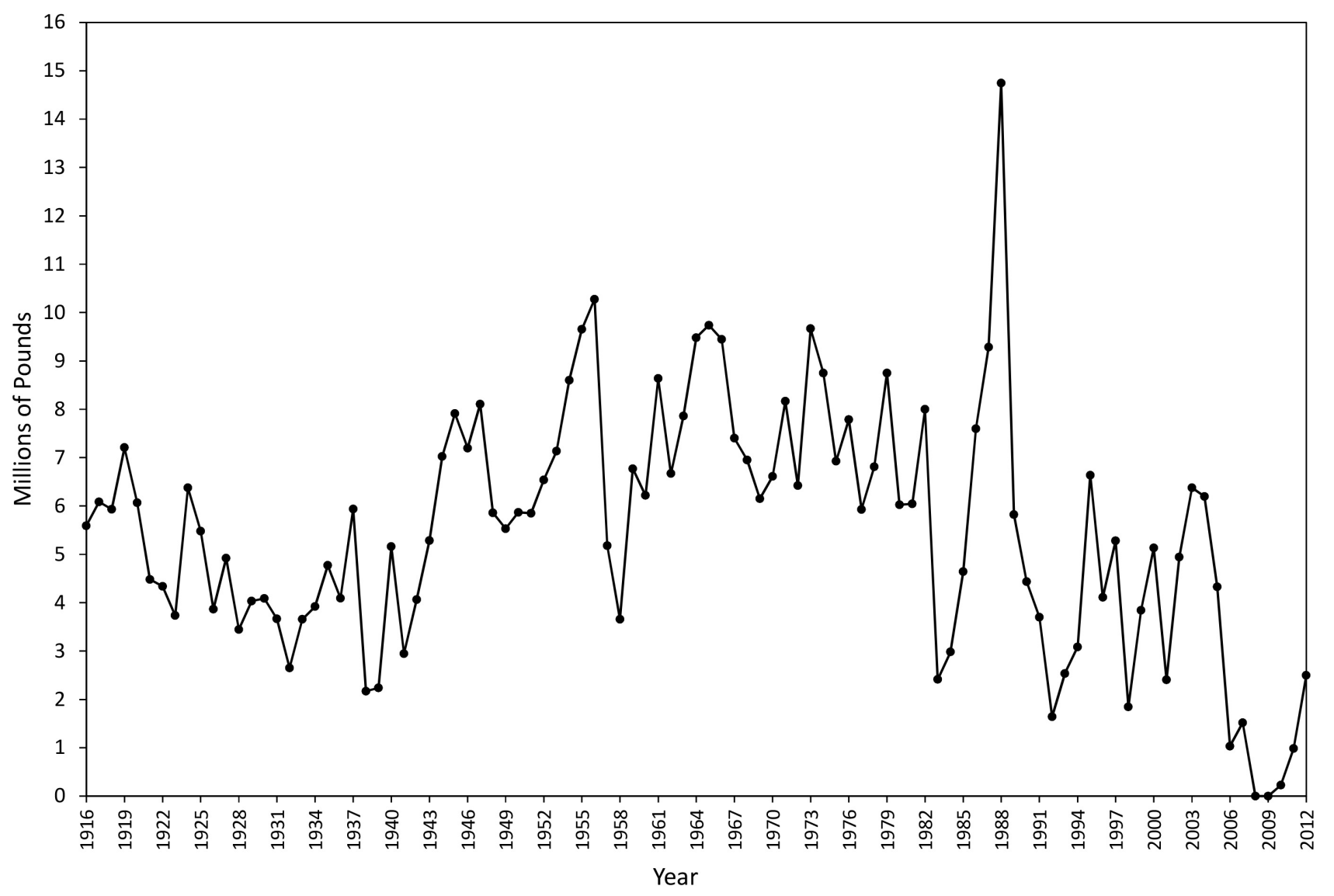

Figure 3.-California ocean commercial salmon landings, 1916-2012 (sources: Leet et al., 2001 and PacFIN).

averaging $\$ 0.34 / \mathrm{lb}$ ), squid prices generally increased from $\$ 0.11-0.22 / \mathrm{lb}$ during 1986-2002 to $\$ 0.25-0.33 / \mathrm{lb}$ in 2003-12. Since 1985, squid has vied with CPS as the largest volume fishery in California. Since 2009, squid landings (205-288 million lb) have consistently exceeded CPS landings (65-105 million $\mathrm{lb}$ ).

Squid availability is highly susceptible to environmental conditions (Koslow and Allen, 2011); recordlow landings in 1983, 1984, 1992, and 1998 (1.2-28.9 million lb) coincided with major El Niño events that adversely affected the availability of squid to the fishery. State regulations include quotas, restricted access, weekend closures, and restrictions on the use of squid attracting lights to mitigate effects on seabird colonies (CDFG, 2005). The 2012-13 season was the third consecutive season to be curtailed due to the quota constraint (CDFW, 2013).

\section{CPS Seine}

CPS seine landings averaged 131 million lb during 1981-2012. Landings exceeded 200 million $\mathrm{lb}$ in 1981-82 and 2007, and fell below 100 million $\mathrm{lb}$ in 1992-94 and 2010-12. During 198182, CPS landings were about evenly split between anchovy and Pacific and jack mackerel. The anchovy reduction fishery ceased operation in the late 1980's due to record low reduction prices (Jacobson and Thomson, 1993). The mackerel share of CPS landings grew to $86-95 \%$ during 1983-90, then declined to $50 \%$ by 1992 as the sardine fishery recovered after its collapse in the 1950's.

During 1995-2012, the species composition of CPS landings was 76\% sardine, $14 \%$ mackerel, and 10\% an- chovy on an average annual basis. As sardine abundance has increased, the stock has expanded its northward range from Mexico and California to include Oregon, Washington, and British Columbia (Hill et al., 2014). The sardine harvest control rule is notable for incorporating ocean temperature as a constraint on harvest to reflect the effect of environmental conditions on recruitment. ${ }^{6}$

\section{Other Fisheries}

Although much lower than squid and CPS landings, landings in the sea urchin, Strongylocentrotus spp., nonwhiting groundfish trawl, and Dunge-

${ }^{6}$ The temperature component of the sardine harvest control rule was abandoned in 2012 but reinstated in 2014 on the basis of further research indicating the appropriateness of its inclusion using a different temperature index (Lindegren and Checkley, 2013; Jacobson and McClatchie, 2013). 


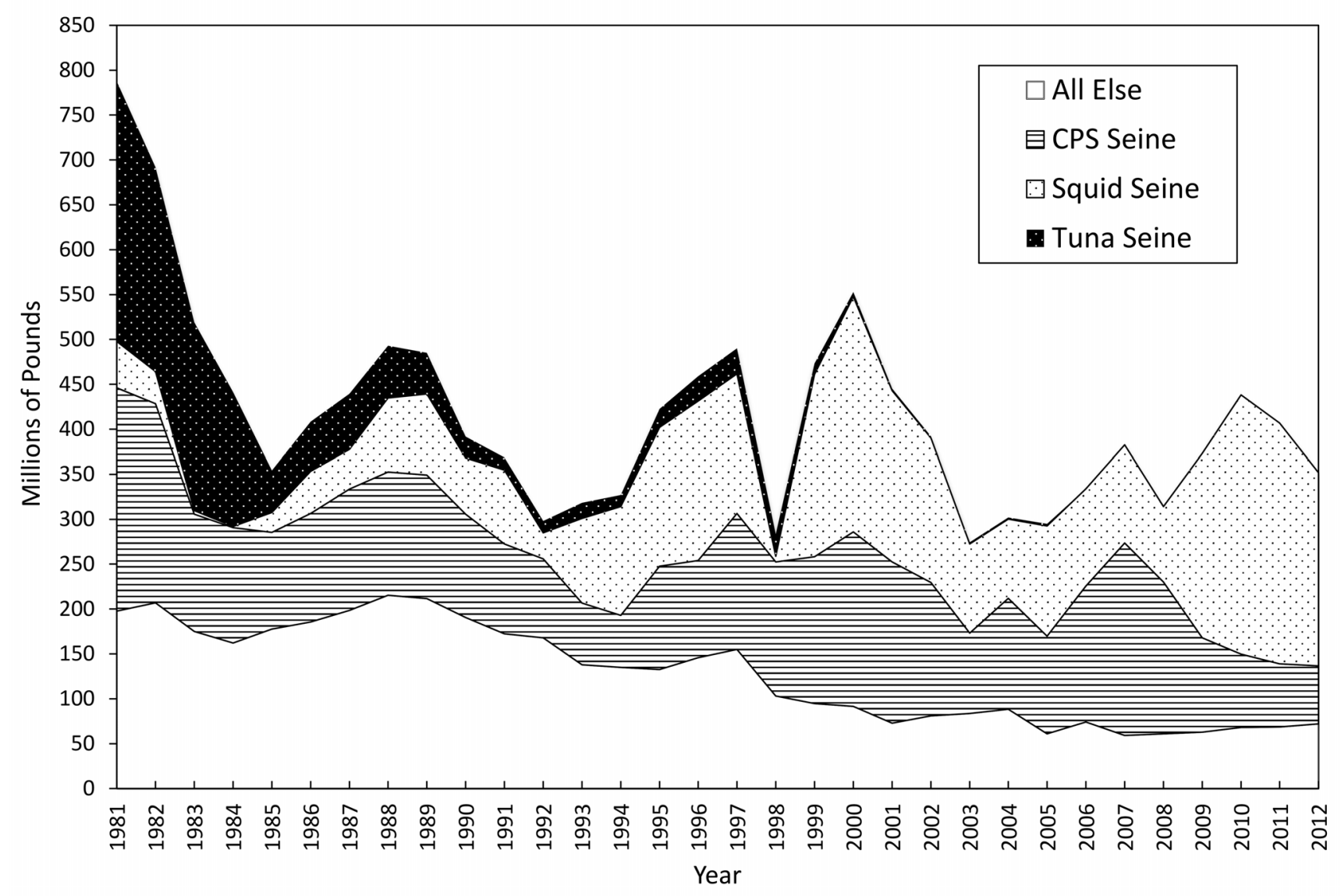

Figure 4.-California commercial landings, including landings in selected fisheries (tuna seine, squid seine, CPS seine), 1981-2012.

ness crab fisheries have nonetheless been substantial, typically ranging in the tens of millions of pounds.

- The fishery for sea urchin roe (uni) originally developed for the Japanese market and later expanded to include the domestic market as U.S. consumers acquired a taste for sushi (Kalvass and RogersBennett, 2001). Urchin landings increased from 15-26 million $\mathrm{lb}$ during 1981-85 to 33-52 million lb during 1986-92. Landings declined to 27 million $\mathrm{lb}$ in 1993 and 18 million $\mathrm{lb}$ by 1997 and have been relatively stable (10-15 million lb) since 1998.

- Landings in the groundfish trawl fishery steadily declined from 77 million $\mathrm{lb}$ in 1981 to 10 million $\mathrm{lb}$ in 2012. In the late 1990's-early 2000's, the PFMC declared eight groundfish stocks "overfished" (Ralston, 2002b) and implemented major reductions in harvest limits for both overfished stocks and target species that co-mingle with these stocks in the fishery, area and gear restrictions to minimize incidental take of overfished stocks, and other rebuilding measures. ${ }^{7}$ An industry-funded buyback was implemented in 2003 to address the overcapacity problem, which had been exacerbated by the

${ }^{7}$ These unprecedented restrictions were intended to put the fishery on a more sustainable trajectory after major flaws were uncovered in the scientific information previously used to set harvest limits. According to Ralston (2002a), “...for years there were serious flaws in the scientific advice that was presented to the council as the foundation of its decision making. The deficiencies were not easy to foresee and were due to a combination of inadequate data and fishery productivity that was far lower than anyone imagined." reduction in harvest opportunities (NMFS, 2004). A catch share program was implemented in 2011 that increased individual accountability for incidental take of overfished stocks while also providing additional harvest opportunity for targeted species (PFMC, 2010a; PFMC, 2010b). Groundfish trawl activity is monitored via landings receipts, logbooks, satellite-based vessel monitoring systems, and $100 \%$ observer coverage; groundfish processors as well as vessels are subject to mandatory economic data collection requirements.

- Landings in the Dungeness crab fishery increased from 4-14 million $\mathrm{lb}$ during 1981-2002 to 9-26 million $\mathrm{lb}$ in 2003-12. Landings exceeded 20 million $\mathrm{lb}$ in 6 of the 10 years since 2003 . 


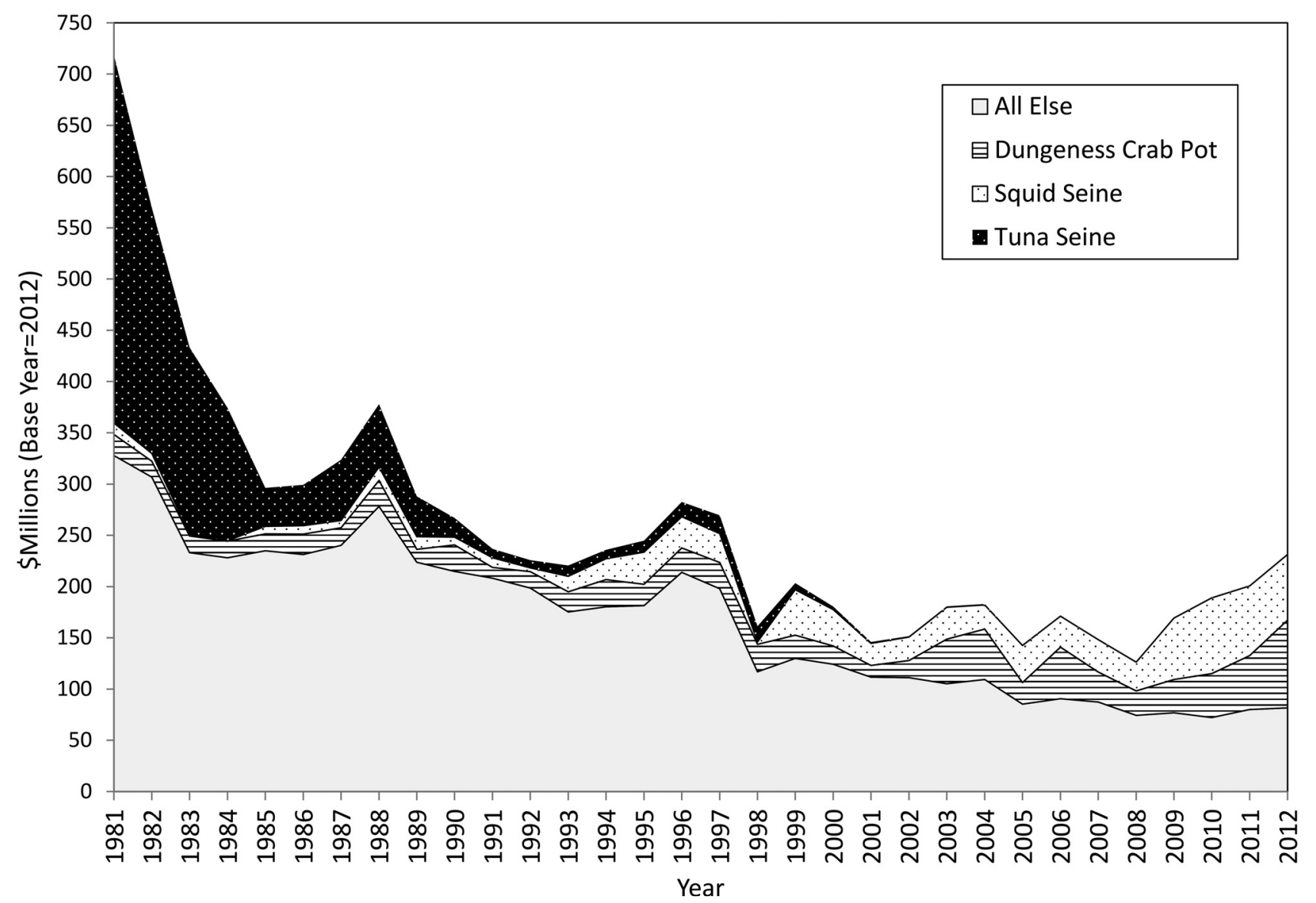

Figure 5.- Ex-vessel revenues in California commercial fisheries, including revenues in selected fisheries (tuna seine, squid seine, Dungeness crab pot), 1981-2012.

\section{Ex-Vessel Revenues}

Figure 5 depicts California ex-vessel revenues during 1981-2012. Unlike statewide participation and landings trends, which have been driven by a handful of fisheries, it is difficult to identify any specific fisheries that have consistently dominated revenues. However several fisheries (tuna seine, Dungeness crab, squid seine) have been particularly influential in certain years of the time series. Statewide revenues declined from $\$ 634$ million in 1981 to $\$ 385$ million in 1983 , largely due to closure of the southern California tuna canneries. Revenues continued to fall from \$296-378 million in 1984-89 to \$187-240 million in $1990-97$ to $\$ 126-192$ million in 1998-2010. The trend reversed in
2011-12 (\$205-232 million), when an upsurge in Dungeness crab and squid seine revenues caused statewide revenues to increase to levels not experienced since 1999. Since 2003, Dungeness crab pot and squid seine together have dominated statewide revenues - accounting for an average $47 \%$ of revenues during $2003-08$ and $61 \%$ in $2009-12$.

California fisheries exhibit a variety of revenue trends that reflect changes in landings and prices over time. Fisheries that have experienced fairly persistent revenue increases since 1981 include the following:

- Dungeness crab revenues, like landings, increased markedly in the early 2000's. Revenues increased from \$10.4-26.8 million in 1981-2002 to \$21.1-52.6 mil- lion in 2003-11, then peaked at $\$ 85.6$ million in 2012. The exvessel price in $2012(\$ 3.32 / \mathrm{lb})$ rivaled previous highs experienced in 1983-84 (\$3.06/lb) and 2001 $(\$ 3.23 / \mathrm{lb})$. Record low salmon harvests in the late 2000's likely encouraged diversion of salmon troll effort to the Dungeness crab fishery.

- Due to the El Niño effects noted earlier, squid seine revenues (like landings) reached lows in 1983, 1984, 1992, and 1998 (\$0.6-3.7 million). However (excluding El Niño years), the revenue trend has been generally upward, increasing from \$7.0-15.1 million in 1981-93 to \$20.6-44.3 million in 1994-2008 to \$59.9-73.9 million in 2009-12. Squid prices dur- 
ing 2003-12 (\$0.25-0.33/lb) were exceeded only in 1983-85 (\$0.33$0.47 / \mathrm{lb})$ and 1998 (\$0.34/lb). However 1983-85 and 1998 were low years in terms of landings, while landings in the post-2003 years have been exceptionally high (including record highs of 268.0 288.4 million $\mathrm{lb}$ in 2010-11).

- California spiny lobster, Panulirus interruptus, pot revenues increased from \$3.4-4.0 million in 1981-87 to \$5.0-6.8 million in 1988-95, then increased further from \$5.7-9.1 million in 19962009 to $\$ 11.8-13.7$ million in 2010-12. Prices reached record highs (\$15.68-17.23/lb) in these last three years. Management measures for this fishery include limited entry, gear restrictions, size limits, and season and area closures. CDFW recently drafted the California Spiny Lobster Fishery Management Plan $\left(\mathrm{CDFW}^{8}\right)$, which considers additional restrictions as well as modifications to current ones.

Fisheries that have experienced fairly persistent revenue decreases since 1981 include the following:

- CPS seine revenues declined from $\$ 41.0$ million in 1981 to $\$ 20.7$ million in 1984, then fell to \$5.619.1 million in 1985-2009 and \$5.5-5.6 million by 2010-12. The majority of CPS harvest from the early 1990's to 2012 has consisted of sardine. Factors contributing to the revenue decline in recent years include reductions in sardine stock abundance since 2007 and diversion of CPS effort to the more lucrative squid fishery.

- Non-whiting groundfish trawl revenues fell from \$31.7-40.2 million in 1981-89 to $\$ 23.0-33.6$ million in 1990-97, then declined more precipitously from $\$ 19.3$ million in 1998 to $\$ 6.7$ million in

${ }^{8}$ CDFW. 2016. Draft California spiny lobster fishery management plan. 6 Jan. 2016. Calif. Dep. Fish Wildlife, Marine Region, Monterey, Calif., 227 p. (Avail. online at http://www.fgc. ca.gov/public/notices/Lobster_Fishery_Management_Plan_010616_Draft.pdf)
2012. These declines are consistent with the decline in groundfish trawl landings described earlier.

- Salmon troll revenues (like landings) have been highly variable, with unpredictable river and ocean conditions contributing to the variability in landings. Probably the most notable change in management has been the adoption of restrictive weak-stock management policies since the early 1990's. Average annual revenue was \$30.9 million in 1981-90 and \$10.7 million in 1991-2007. The earlier period includes the two highest revenue years, $\$ 45.5$ million in 1987 and \$72.1 million in 1988. After the unprecedented fishery closures in 2008-09, revenue rebounded to $\$ 12.9$ million by 2012 . Prices fell from $\$ 5.54 / \mathrm{lb}$ in 1981 to $\$ 1.89-2.62 / \mathrm{lb}$ by $1995-2003$, largely due to competition from cheaper, imported Atlantic salmon (Fig. 6). The steady decline in prices exacerbated the effect of declining landings on revenues during this period. However, since 2006 , salmon prices have rebounded to $\$ 4.48-5.69 / \mathrm{lb}$, partly due to development of niche markets for wild salmon and record low California harvests in the late 2000's.

- Both the tuna seine and albacore troll fisheries were affected by the southern California cannery closures in the early 1980 's. Tuna seine revenues fell from $\$ 359.0$ million in 1981 to $\$ 129.4-239.8$ million in $1982-84$ to $\$ 6.5-18.7$ million by 1990-99; revenues have been well below $\$ 550,000$ since 2006. Albacore troll revenues fell from $\$ 50.3$ million in 1981 to \$18.1-30.1 million in 1982-84, then \$3.0-16.4 million in 1985-2004 and \$1.0-2.6 million in 2005-12.

- Abalone, Haliotis spp., revenues declined from \$4.7 million in 1981 to $\$ 1.4$ million in 1997 , with prices, which increased from $\$ 3.88-4.22 / \mathrm{lb}$ during $1981-83$ to $\$ 12.72-13.43 /$ lb in $1994-97$, more than offset by the decline in landings. The commercial fishery has been closed since 1998 due to low abundance variously attributed to overharvest, sea otter, Enhydra lutris, predation, and withering syndrome (Haaker et al., 2001).

Fisheries with revenues that peaked in the mid-1980's to early 1990's before beginning their downward trend include the following:

- Sea urchin revenues increased from \$6.9-11.1 million in 198185 to a peak of \$33.4-52.3 million during 1988-95, then declined to $\$ 5.7-8.2$ million by $2005-12$. During 1991-94, urchin was the highest revenue fishery in California. Urchin prices increased from $\$ 0.38-0.52 / \mathrm{lb}$ in $1981-87$ to a peak of $\$ 1.43-1.54 /$ lb in $1993-$ 95, then declined to \$0.53-0.73/ $\mathrm{lb}$ by $2005-12$. Landings peaked earlier (1986-92) than revenues (1988-95), due to the trend in prices. The decline in this fishery has been variously attributed to infrequent recruitment and intensive harvesting, particularly in northern California, and the depressed Japanese market (Kalvass and Rogers-Bennett, 2001).

- Whiting trawl revenues increased from $\$ 0.3$ million in 1981 to a peak of \$1.7-1.8 million in 198889 , decreased to $\$ 0.2-1.1$ million during 1992-2010 and virtually disappeared in 2011-12. The recent disappearance of this fishery in California has been attributed to trading of whiting quota pounds for more lucrative species by California participants in the groundfish trawl catch share program (CDFW, 2013). Even prior to the catch share program, Oregon and Washington (where whiting processing capacity is concentrated) accounted for the vast majority of west coast whiting landings.

- Revenues in the swordfish drift gillnet fishery increased from $\$ 4.3$ million in 1981 to $\$ 22.2$ million in 1985 but declined to less than $\$ 800,000$ by $2010-12$; landings exhibited a similar pattern. 


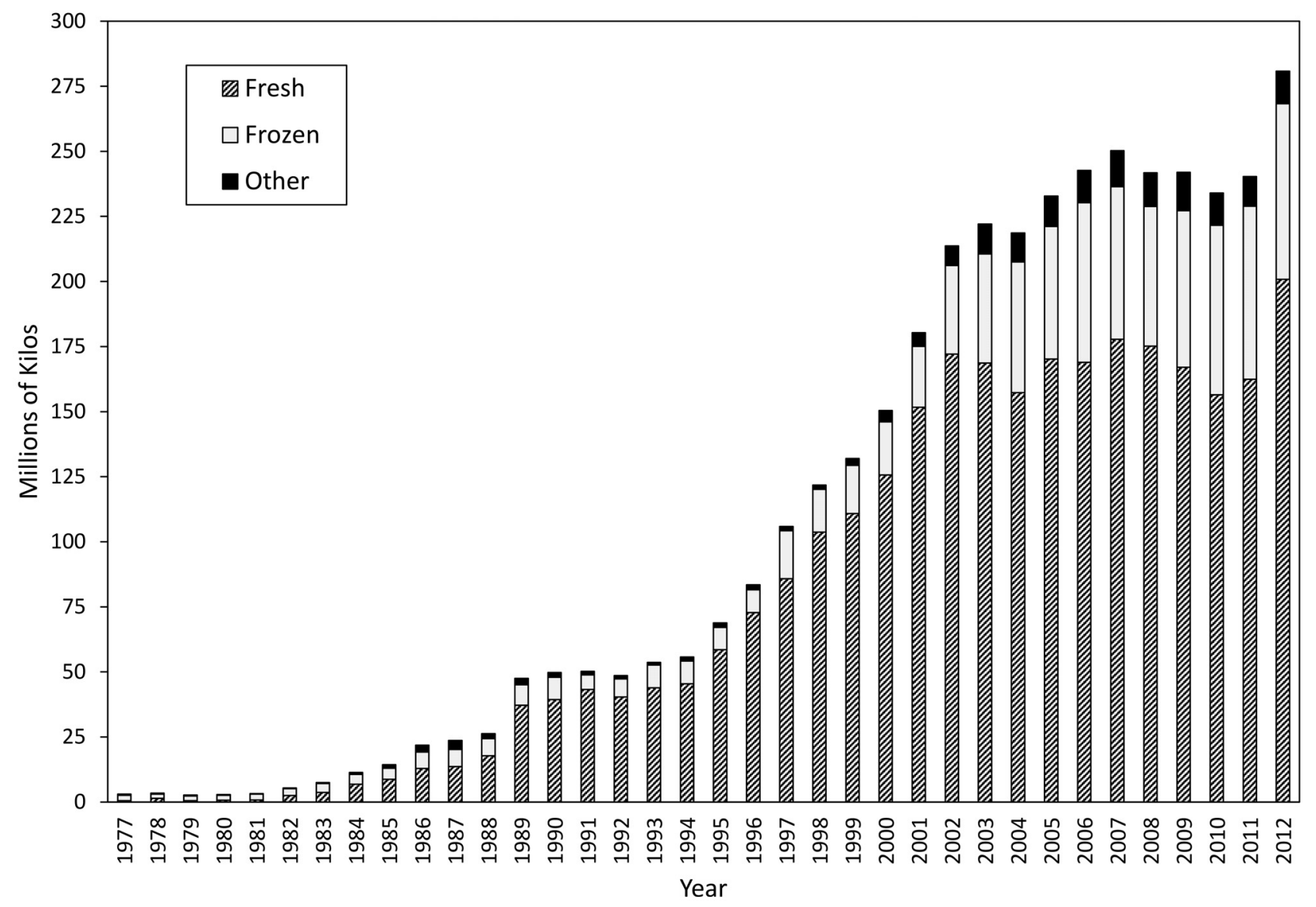

Figure 6.-U.S. salmon imports by product type (fresh, frozen, other), 1976-2012 (source: Fisheries Statistics Division, NMFS Office of Science and Technology).

Swordfish prices declined from $\$ 4.69-7.07 / 1 \mathrm{~b}$ during 1981-96 to $\$ 2.95-4.52 / 1 \mathrm{~b}$ in $1997-2012$. Time and area closures implemented in 2001 by the PFMC to reduce incidental take of migratory turtles have notably diminished the fleet's access to productive fishing grounds (PFMC, 2013b). Drift gillnet vessels are subject to other management measures such as limited entry, logbook and observer requirements, and "pingers" to deter marine mammals.

- Groundfish gillnet revenues increased from \$2.9 million in 1981 to a peak of $\$ 8.5$ million in 1986 , then declined to $\$ 4.8$ million by 1990 and have been negligible since the late 1990's. In 1990, California voters passed Propo- sition 132, which banned the use of gillnets in state waters by 1994 (Lyons et al., 2013). This closure has been largely responsible for the reduction in nearshore gillnet activity over the past two decades.

Fisheries that did not exhibit any consistent revenue trend during 19812012 include the following:

- The groundfish fixed-gear fishery experienced highly variable revenues, with lows in 1984-85 and 2002-05 (\$5.5-6.5 million), and highs in 1982, 1992, 1995-97, and 2010-11 (\$13.4-17.6 million). The fixed gear fishery targets sablefish and other groundfish (mostly rockfishes). Sablefish landings declined from 6.8-8.9 million $\mathrm{lb}$ in 1981-83 to $1.1-1.9$ million $\mathrm{lb}$ by 1998-2008, then increased to $2.6-$
4.2 million $\mathrm{lb}$ in 2009-12. Nearshore rockfish landings increased from an average of $590,000 \mathrm{lb}$ during $1981-90$ to $1.3-1.8$ million lb in 1991-98 (fueled by development of the live fish market), but have been consistently less than $600,000 \mathrm{lb}$ since 2003. Other rockfish landings were 2.7-6.8 million lb during 1981-98 (except for 1992, when landings peaked at 8.5 million $\mathrm{lb}$ ), then declined to $0.8-$ 1.4 million lb in 1999-2012. Average prices for nearshore rockfishes (including those caught dead as well as live) increased from $\$ 0.93$ / $\mathrm{lb}$ during $1981-85$ to $\$ 5.51 / \mathrm{lb}$ in 2011-12. Prices also increased over the same two periods for other rockfishes (from $\$ 1.06$ to $\$ 2.53$ / lb) and sablefish (from $\$ 0.66$ to 


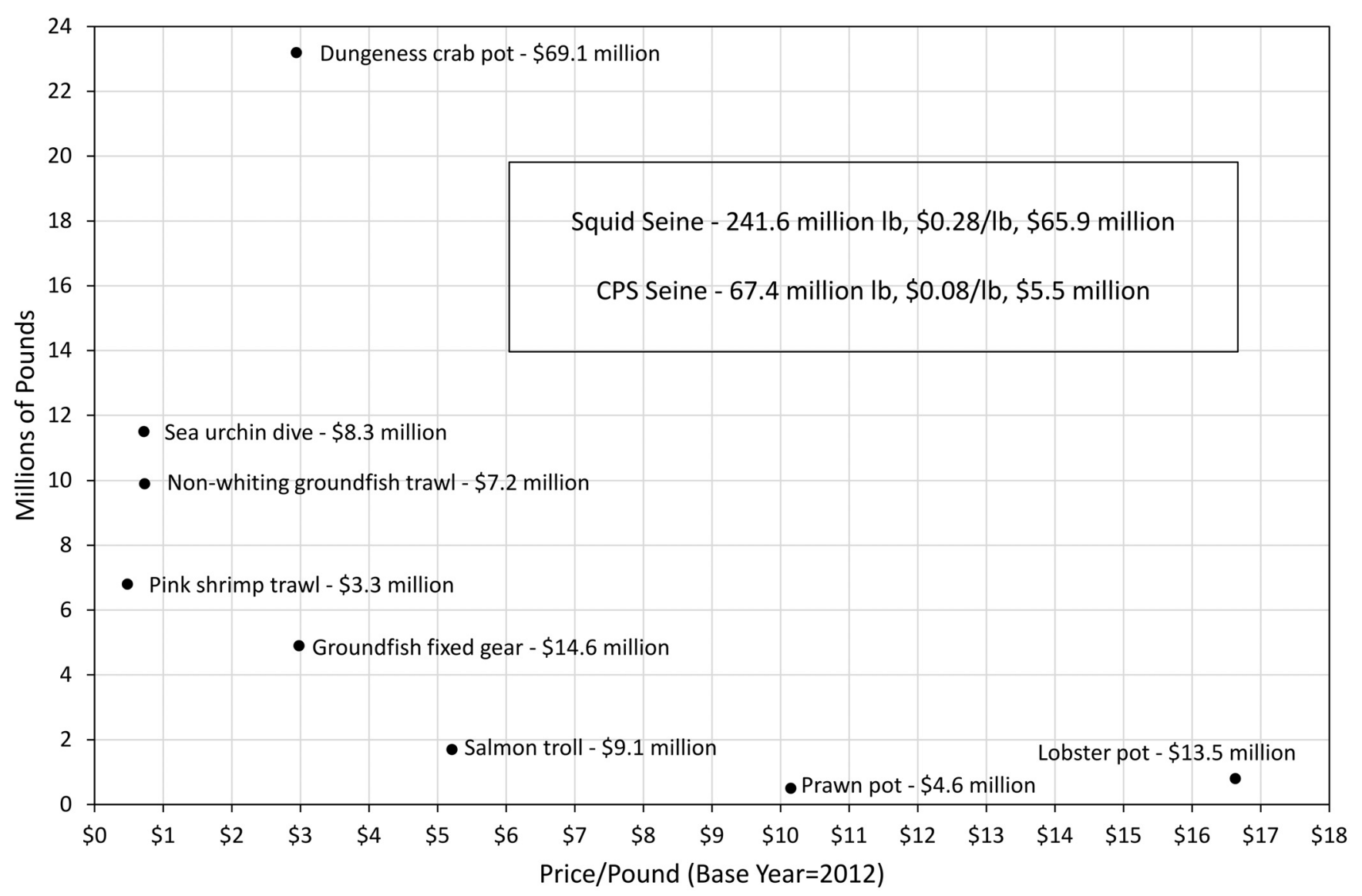

Figure 7.- -Average annual landings, revenue and prices in California's top-ten revenue fisheries in 2011-12. High-volume squid seine and CPS seine fisheries noted but not graphed to better distinguish landings in other fisheries on y-axis.

$\$ 2.81 / \mathrm{lb})$. These price increases have moderated the impact of falling landings. The contributions of sablefish, nearshore rockfish, and other rockfish to total revenues averaged $38 \%, 25 \%$, and $27 \%$, respectively, during 1981-2012. The sablefish share declined from $45 \%$ during $1981-85$ to a low of $12 \%$ in 1993 , then increased to $65 \%$ by 2011-12. The nearshore rockfish share increased from $6 \%$ during $1981-85$ to a high of $50 \%$ in 1998 , then declined to $16 \%$ by $2011-12$. The other rockfish share increased from $47 \%$ in $1981-85$ to a high of $69 \%$ in 1989 then declined to $19 \%$ by $2011-12$.

- The hagfish, Eptatretus stoutii, pot fishery emerged briefly in the late 1980 's with landings ex- ported for the eelskin market in the Republic of Korea. The fishery then disappeared and reemerged in 2007, with hagfish now sold in South Korea's live fish market for human consumption (CDFG, 2008:31-34). Annual revenues were \$0.6-3.6 million in 198890 and \$0.6-1.6 million in 2007-12.

Figure 7 depicts average annual landings, prices, and revenues in 2011-12 for the ten California fisheries that generated at least $\$ 3$ million in average annual revenue in those 2 years. The squid seine and CPS seine fisheries are noted but not graphed in Figure 7 , as the magnitude of their landings (242 million and 67 million $1 b$, respectively) would have obscured differences in landings on the y-axis for the other eight fisheries. Figure 7 illustrates the heterogeneity of species, gear types, and price-landings combinations associated with California's highest-revenue fisheries.

\section{Spatial Distribution of Fishing Activity}

This section describes fishing activity in five designated regionsSouthern California, South Central California, Central California, North Central California, and Northern California-and how activity is distributed among ports within each region (Figure 8 gives region and port locations, ignoring the numbers for now). Table 2 shows how vessel participation, landings, and revenues in each region have varied over time. Regional differences reflect the spa- 


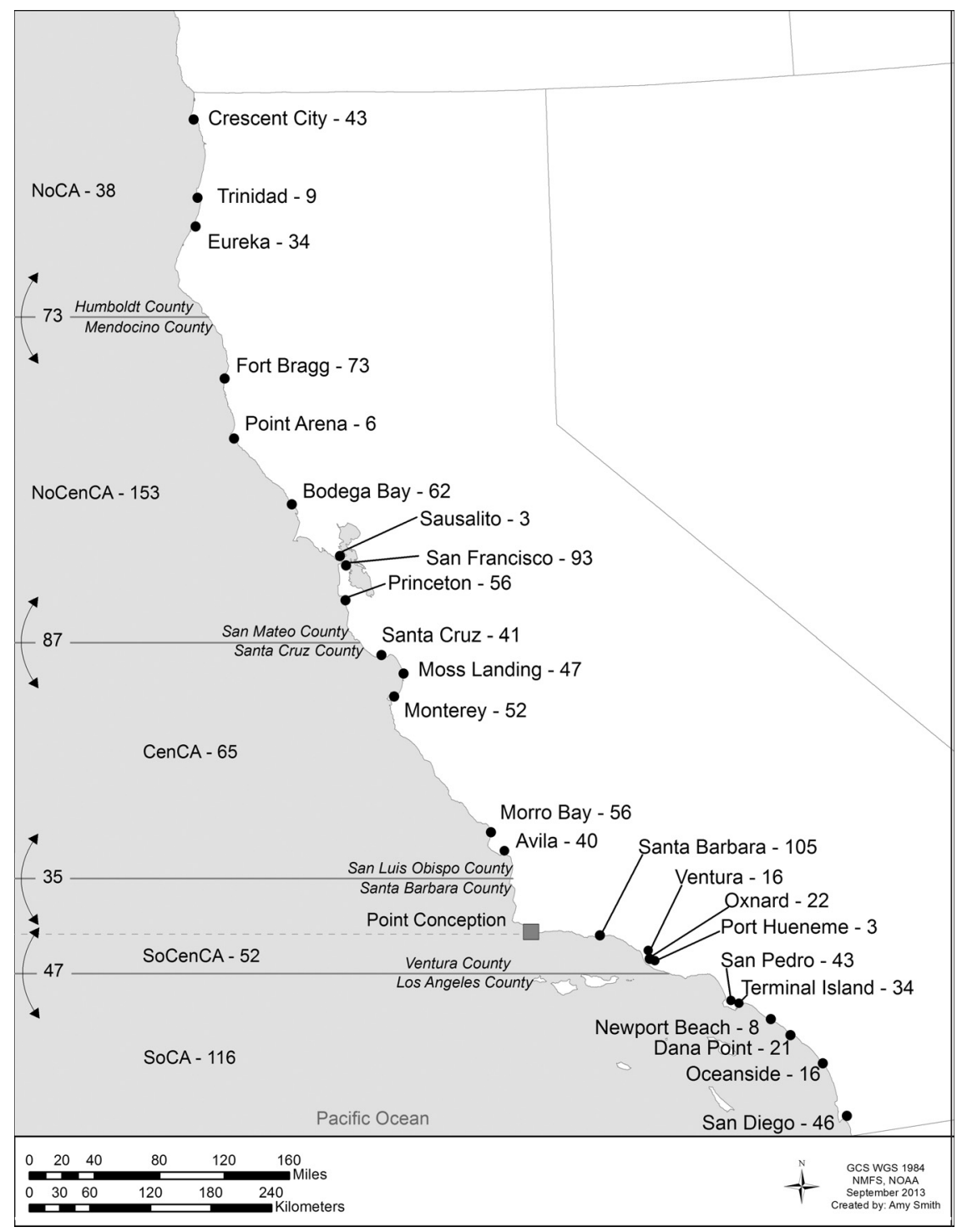

Figure 8.-Major California fishing ports by region, and average annual number of boats fishing exclusively in each port, each region, and adjacent regions, 2011-12.

tial distribution of high-participation, high-volume, and high-revenue fisheries across the state.

Vessel participation was consistently highest in North Central California in all 32 years of the time series, with an average $42 \%$ of active vessels landing fish in this region. The majority of the salmon troll fleet is concentrated in this region as well as a sizeable number of Dungeness crab and groundfish fixed gear vessels. Vessel participation was lowest in South Central California in 12 of the 32 years (mostly from the
Chinook) that disproportionately constrained the salmon troll fishery in that region (PFMC, 2016a).

Landings were highest in Southern California in 31 of the 32 years. This region accounted for an average $66 \%$ of statewide landings during 1981-84 and $42 \%$ in 1985-2012, largely due to the concentration of the high volume seine fisheries for tuna, squid, and CPS in this region. North Central California and Northern California were the lowest landing regions, each accounting for an average $10 \%$ of statewide landings during 1981-2012; these are the only regions that lack squid and CPS fisheries. Revenues were highest in Southern California in 21 of the 32 years, partly driven by the same seine fisheries that accounted for high landings in this region. Revenues were lowest in Central California in 21 of the 32 years (all after the late 1980's). Although Central California has a number of major fisheries in common with other regions, groundfish trawl revenues are consistently lower in this region than North Central and Northern California, salmon troll revenues are consistently lower here than North Central California, and squid seine revenues have been lower here than Southern and South Central California in most years since 1995 .

For each region, Table 3 identifies fisheries that provided at least $5 \%$ of regional revenues in at least one of the designated time intervals. Some of the fisheries in Table 3 are region-specific (tuna seine in Southern California; Pacific herring, Clupea pallasii, net in North Central California). However, most fisheries occur in multiple regions, with one fishery (groundfish fixed gear) occurring statewide. The highest-revenue fisheries in each region in 2011-12 were squid seine in Southern and South Central California, squid seine and groundfish fixed gear in Central California, and Dungeness crab pot in North Central and Northern California. Comparison with previous time intervals indicates the fluidity of the revenue shares over time.

Figures 9a-e illustrate the port contributions to regional revenue and how 
these contributions have changed over time.

- The highest revenue ports in Southern California are Terminal Island and San Pedro (Fig. 9a). The closure of Terminal Island and San Diego tuna canneries in the early 1980's had an immediate negative effect on San Diego's revenue share; however, non-tuna landings at Terminal Island have remained sufficiently high for that port to retain its status as a high revenue port. Revenue contributions by Oceanside, Dana Point, and Newport Beach have been much more modest but have increased over time. Some notable fisheries identified with specific ports include lobster pot in San Diego, Oceanside, and Dana Point; groundfish fixed gear in Oceanside, Dana Point, and Newport Beach; and squid seine and CPS seine in San Pedro and Terminal Island.

- In South Central California, revenue shares have generally increased for Port Hueneme and Ventura and decreased for Oxnard and Santa Barbara; however, all four ports continue to contribute substantially to regional revenue (Fig. 9b). Some notable fisheries identified with specific ports include lobster pot in Santa Barbara, squid seine in Port Hueneme and, to a lesser extent, Ventura, and groundfish fixed gear in Santa Barbara.

- In Central California, Moss Landing is the highest revenue port, followed by Morro Bay and Monterey, then Avila and Santa Cruz (Fig. 9c). Some notable fisheries identified with specific ports include Dungeness crab pot in Moss Landing and Santa Cruz, squid seine in Moss Landing and Monterey, and groundfish fixed gear in Morro Bay and, to a lesser extent, Moss Landing and Avila.

- In North Central California, the highest revenue port generally has been San Francisco, followed by Fort Bragg, then Princeton and

Table 2. - Number of boats, landings (millions of pounds), and revenue (\$millions, base year=2012), 1981-2012, by region and time interval. Number of boats not additive across regions as some boats fish in multiple regions. Statewide landings and revenues are slightly higher than sum across regions as not all landings and revenues can be attributed to a region.

\begin{tabular}{|c|c|c|c|c|c|c|c|c|}
\hline & $\begin{array}{c}1981-2012 \\
\text { Avg }\end{array}$ & $\begin{array}{c}1981-85 \\
\text { Avg }\end{array}$ & $\begin{array}{c}1986-90 \\
\text { Avg }\end{array}$ & $\begin{array}{c}1991-95 \\
\text { Avg }\end{array}$ & $\begin{array}{c}1996-2000 \\
\text { Avg }\end{array}$ & $\begin{array}{c}2001-05 \\
\text { Avg }\end{array}$ & $\begin{array}{c}2006-10 \\
\text { Avg }\end{array}$ & $\begin{array}{c}2011-12 \\
\text { Avg }\end{array}$ \\
\hline \multicolumn{9}{|c|}{ Southern California } \\
\hline \#Boats & 743 & 1,348 & 928 & 775 & 642 & 494 & 408 & 402 \\
\hline Landings & 194.8 & 360.0 & 207.5 & 130.2 & 190.4 & 144.9 & 148.9 & 162.6 \\
\hline Revenue & 87.5 & 263.8 & 95.7 & 45.9 & 57.6 & 36.5 & 39.7 & 52.4 \\
\hline \multicolumn{9}{|c|}{ South Central California } \\
\hline \#Boats & 469 & 548 & 581 & 626 & 488 & 345 & 295 & 301 \\
\hline Landings & 80.5 & 41.0 & 58.6 & 72.9 & 125.3 & 76.3 & 99.2 & 105.1 \\
\hline Revenue & 33.9 & 20.8 & 31.2 & 44.6 & 39.4 & 25.8 & 37.9 & 43.4 \\
\hline \multicolumn{9}{|c|}{ Central California } \\
\hline \#Boats & 855 & 1,376 & 1,141 & 1,045 & 812 & 560 & 340 & 493 \\
\hline Landings & 56.9 & 53.4 & 43.9 & 44.4 & 60.9 & 67.0 & 73.6 & 52.5 \\
\hline Revenue & 23.7 & 31.1 & 31.5 & 24.7 & 24.0 & 17.9 & 13.5 & 23.2 \\
\hline \multicolumn{9}{|c|}{ North Central California } \\
\hline \#Boats & 1,453 & 2,477 & 2,432 & 1,566 & 1,108 & 876 & 557 & 702 \\
\hline Landings & 45.6 & 62.1 & 80.3 & 52.2 & 38.0 & 26.4 & 17.8 & 37.1 \\
\hline Revenue & 49.5 & 59.0 & 75.4 & 52.5 & 44.1 & 34.4 & 26.7 & 61.4 \\
\hline \multicolumn{9}{|c|}{ Northern California } \\
\hline \#Boats & 591 & 1,280 & 758 & 597 & 445 & 322 & 279 & 252 \\
\hline Landings & 40.2 & 47.3 & 56.8 & 49.3 & 38.5 & 27.2 & 29.3 & 22.2 \\
\hline Revenue & 35.4 & 40.5 & 43.2 & 38.1 & 33.1 & 26.8 & 30.0 & 38.0 \\
\hline \multicolumn{9}{|c|}{ Total California } \\
\hline \#Boats & 3,359 & 5,776 & 4,710 & 3,699 & 2,847 & 2,143 & 1,605 & 1,800 \\
\hline Landings & 418.4 & 564.1 & 447.6 & 349.4 & 453.3 & 342.1 & 369.1 & 380.2 \\
\hline Revenue & 230.6 & 415.9 & 278.7 & 206.2 & 198.4 & 141.5 & 147.8 & 218.6 \\
\hline
\end{tabular}

Bodega Bay (Fig. 9d). Point Arena and Sausalito once accounted for over $5 \%$ of regional revenue but have been minor ports in recent years. Some notable fisheries identified with specific ports include Dungeness crab pot in San Francisco, Bodega Bay, and Princeton; groundfish trawl in Fort Bragg; salmon troll in Fort Bragg, Bodega Bay, San Francisco and Princeton; and groundfish fixed gear in Fort Bragg.

- In Northern California, the highest revenue ports have been Crescent City and Eureka (Fig. 9e). Fields Landing's contribution to regional revenue peaked at $21 \%$ in 1985 but has been much less than $5 \%$ in recent years, while Trinidad's contribution has been low but fairly stable over time. Some notable fisheries identified with specific ports include Dungeness crab pot in Crescent City and Eureka, shrimp trawl in Crescent City, and groundfish trawl in Eureka.

\section{California Fleet Dynamics}

Figure 10 depicts the number of boats that made at least one trip in California, the number of "California boats" (boats that derived the plurality of their revenue from California as opposed to Oregon and Washington landings), and the number of California boats whose annual revenue exceeded $\$ 5,000$. Almost all boats that land fish in California qualify as "California boats" in terms of plurality of revenue. The total number of California boats declined from 6,378 in 1981 to 1,432 in 2009 , then increased to 1,809 by 2012 . Following a similar pattern, the number of California boats earning more than $\$ 5,000$ declined from 3,173 in 1981 to 1,082 in 2009 , then increased to 1,390 by 2012 .

California boats earning less than $\$ 5,000$ comprise a substantial though declining proportion of the California fleet. Many of these vessels are salmon trollers operated by fishermen who are semi-retired or also engaged in other occupations. The proportion of California vessels earning less than $\$ 5,000$ has decreased from $50 \%$ in 1981 to $23 \%$ in 2012 . This change is consistent with the precipitous decline in the number of salmon trollers over time (Fig. 2). The remainder of this section focuses on "California boats" in terms of vessel-level activity and performance. 
Table 3.-Relative distribution of regional revenue among fisheries, 1981-2012, by region and time interval.

\begin{tabular}{|c|c|c|c|c|c|c|c|c|}
\hline & $\begin{array}{c}981-2012 \\
\text { Avg }\end{array}$ & $\begin{array}{c}1981-85 \\
\text { Avg }\end{array}$ & $\begin{array}{c}1986-90 \\
\text { Avg }\end{array}$ & $\begin{array}{c}1991-95 \\
\text { Avg }\end{array}$ & $\begin{array}{c}1996-2000 \\
\text { Avg }\end{array}$ & $\begin{array}{c}2001-05 \\
\text { Avg }\end{array}$ & $\begin{array}{c}2006-10 \\
\text { Avg }\end{array}$ & $\begin{array}{c}2011-12 \\
\text { Avg }\end{array}$ \\
\hline \multicolumn{9}{|l|}{ Southern California } \\
\hline Tuna Seine & 0.24 & 0.67 & 0.43 & 0.19 & 0.20 & 0.02 & 0.01 & 0.00 \\
\hline Squid Seine & 0.19 & 0.01 & 0.04 & 0.07 & 0.14 & 0.28 & 0.46 & 0.59 \\
\hline CPS Seine & 0.13 & 0.09 & 0.16 & 0.15 & 0.13 & 0.13 & 0.14 & 0.07 \\
\hline Lobster Pot & 0.09 & 0.01 & 0.05 & 0.09 & 0.08 & 0.11 & 0.15 & 0.17 \\
\hline Urchin Dive & 0.07 & 0.01 & 0.07 & 0.14 & 0.10 & 0.09 & 0.03 & 0.03 \\
\hline Albacore Troll & 0.06 & 0.08 & 0.04 & 0.11 & 0.13 & 0.03 & 0.01 & 0.01 \\
\hline Swordfish Net & 0.05 & 0.06 & 0.08 & 0.06 & 0.04 & 0.03 & 0.03 & 0.00 \\
\hline Swordfish H\&L/Harpoon & 0.05 & 0.01 & 0.02 & 0.03 & 0.08 & 0.15 & 0.02 & 0.00 \\
\hline Groundfish Fixed Gear & 0.05 & 0.02 & 0.03 & 0.07 & 0.05 & 0.07 & 0.06 & 0.04 \\
\hline Subtotal & 0.93 & 0.96 & 0.92 & 0.91 & 0.95 & 0.91 & 0.91 & 0.91 \\
\hline All Else & 0.07 & 0.04 & 0.08 & 0.09 & 0.05 & 0.09 & 0.09 & 0.09 \\
\hline Total & 1.00 & 1.00 & 1.00 & 1.00 & 1.00 & 1.00 & 1.00 & 1.00 \\
\hline \multicolumn{9}{|l|}{ South Central California } \\
\hline Squid Seine & 0.30 & 0.02 & 0.12 & 0.18 & 0.41 & 0.42 & 0.57 & 0.56 \\
\hline Urchin Dive & 0.28 & 0.30 & 0.40 & 0.53 & 0.24 & 0.20 & 0.12 & 0.10 \\
\hline Lobster Pot & 0.07 & 0.05 & 0.04 & 0.04 & 0.06 & 0.10 & 0.09 & 0.11 \\
\hline Abalone Dive & 0.05 & 0.13 & 0.08 & 0.06 & 0.01 & 0.00 & 0.00 & 0.00 \\
\hline Groundfish Fixed Gear & 0.04 & 0.04 & 0.04 & 0.05 & 0.05 & 0.03 & 0.02 & 0.05 \\
\hline CPS Seine & 0.04 & 0.11 & 0.04 & 0.01 & 0.02 & 0.04 & 0.02 & 0.01 \\
\hline Prawn Trawl & 0.03 & 0.05 & 0.02 & 0.02 & 0.08 & 0.03 & 0.02 & 0.01 \\
\hline Halibut Net/Trawl & 0.02 & 0.05 & 0.03 & 0.01 & 0.02 & 0.02 & 0.01 & 0.01 \\
\hline Swordfish Net & 0.02 & 0.07 & 0.03 & 0.01 & 0.00 & 0.00 & 0.00 & 0.00 \\
\hline Shark Net & 0.02 & 0.05 & 0.03 & 0.01 & 0.01 & 0.01 & 0.00 & 0.00 \\
\hline Subtotal & 0.87 & 0.87 & 0.83 & 0.92 & 0.90 & 0.85 & 0.85 & 0.89 \\
\hline All Else & 0.13 & 0.13 & 0.17 & 0.08 & 0.10 & 0.15 & 0.15 & 0.11 \\
\hline Total & 1.00 & 1.00 & 1.00 & 1.00 & 1.00 & 1.00 & 1.00 & 1.00 \\
\hline \multicolumn{9}{|l|}{ Central California } \\
\hline Groundfish Trawl & 0.17 & 0.21 & 0.23 & 0.25 & 0.20 & 0.13 & 0.06 & 0.05 \\
\hline Groundfish Fixed Gear & 0.14 & 0.06 & 0.04 & 0.12 & 0.17 & 0.13 & 0.26 & 0.26 \\
\hline Squid Seine & 0.14 & 0.12 & 0.07 & 0.14 & 0.06 & 0.27 & 0.13 & 0.31 \\
\hline Salmon Troll & 0.14 & 0.13 & 0.23 & 0.16 & 0.14 & 0.14 & 0.03 & 0.09 \\
\hline CPS Seine & 0.10 & 0.06 & 0.02 & 0.04 & 0.09 & 0.10 & 0.30 & 0.08 \\
\hline Swordfish Net & 0.07 & 0.09 & 0.14 & 0.08 & 0.06 & 0.02 & 0.03 & 0.02 \\
\hline Albacore Troll & 0.05 & 0.14 & 0.04 & 0.02 & 0.06 & 0.06 & 0.01 & 0.02 \\
\hline Dungeness Crab Pot & 0.03 & 0.00 & 0.01 & 0.02 & 0.01 & 0.03 & 0.07 & 0.09 \\
\hline Groundfish Net & 0.03 & 0.04 & 0.10 & 0.04 & 0.01 & 0.00 & 0.00 & 0.00 \\
\hline Pink Shrimp Trawl & 0.02 & 0.01 & 0.00 & 0.03 & 0.08 & 0.02 & 0.00 & 0.00 \\
\hline Prawn Pot & 0.02 & 0.00 & 0.00 & 0.01 & 0.02 & 0.04 & 0.06 & 0.04 \\
\hline Subtotal & 0.91 & 0.86 & 0.88 & 0.91 & 0.90 & 0.94 & 0.95 & 0.96 \\
\hline All Else & 0.09 & 0.14 & 0.12 & 0.09 & 0.10 & 0.06 & 0.05 & 0.04 \\
\hline Total & 1.00 & 1.00 & 1.00 & 1.00 & 1.00 & 1.00 & 1.00 & 1.00 \\
\hline \multicolumn{9}{|l|}{ North Central California } \\
\hline Dungeness Crab Pot & 0.23 & 0.05 & 0.07 & 0.08 & 0.18 & 0.31 & 0.51 & 0.63 \\
\hline Salmon Troll & 0.20 & 0.27 & 0.32 & 0.13 & 0.14 & 0.30 & 0.10 & 0.11 \\
\hline Groundfish Trawl & 0.17 & 0.27 & 0.17 & 0.20 & 0.19 & 0.12 & 0.15 & 0.04 \\
\hline Herring Net & 0.13 & 0.25 & 0.14 & 0.18 & 0.18 & 0.06 & 0.02 & 0.01 \\
\hline Urchin Dive & 0.10 & 0.00 & 0.15 & 0.22 & 0.10 & 0.07 & 0.07 & 0.04 \\
\hline Groundfish Fixed Gear & 0.06 & 0.03 & 0.06 & 0.07 & 0.08 & 0.05 & 0.08 & 0.05 \\
\hline Albacore Troll & 0.02 & 0.07 & 0.01 & 0.01 & 0.01 & 0.01 & 0.01 & 0.01 \\
\hline Squid Seine & 0.01 & 0.00 & 0.00 & 0.01 & 0.00 & 0.01 & 0.00 & 0.05 \\
\hline Subtotal & 0.92 & 0.94 & 0.92 & 0.90 & 0.88 & 0.93 & 0.94 & 0.94 \\
\hline All Else & 0.08 & 0.06 & 0.08 & 0.10 & 0.12 & 0.07 & 0.06 & 0.06 \\
\hline Total & 1.00 & 1.00 & 1.00 & 1.00 & 1.00 & 1.00 & 1.00 & 1.00 \\
\hline \multicolumn{9}{|l|}{ Northern California } \\
\hline Dungeness Crab Pot & 0.48 & 0.39 & 0.34 & 0.37 & 0.50 & 0.56 & 0.67 & 0.65 \\
\hline Groundfish Trawl & 0.28 & 0.37 & 0.37 & 0.31 & 0.29 & 0.22 & 0.19 & 0.13 \\
\hline Pink Shrimp Trawl & 0.10 & 0.05 & 0.17 & 0.19 & 0.09 & 0.04 & 0.03 & 0.12 \\
\hline Groundfish Fixed Gear & 0.04 & 0.02 & 0.03 & 0.04 & 0.04 & 0.06 & 0.06 & 0.05 \\
\hline Salmon Troll & 0.03 & 0.11 & 0.06 & 0.00 & 0.00 & 0.02 & 0.01 & 0.02 \\
\hline Albacore Troll & 0.03 & 0.06 & 0.01 & 0.03 & 0.03 & 0.06 & 0.02 & 0.02 \\
\hline Swordfish Net & 0.01 & 0.00 & 0.00 & 0.05 & 0.01 & 0.00 & 0.00 & 0.00 \\
\hline Subtotal & 0.97 & 1.00 & 0.98 & 0.99 & 0.96 & 0.96 & 0.98 & 0.99 \\
\hline All Else & 0.03 & 0.00 & 0.02 & 0.01 & 0.04 & 0.04 & 0.02 & 0.01 \\
\hline Total & 1.00 & 1.00 & 1.00 & 1.00 & 1.00 & 1.00 & 1.00 & 1.00 \\
\hline
\end{tabular}

\section{Vessel Participation and Revenue}

Trends in annual revenue per vessel for California vessels are depicted in Figure 11. Revenue per vessel is characterized in terms of mean and 25th, 50th (median), and 75th percentile values. The skewness of the distribution is reflected in the difference between the mean and median values and the close coincidence of the mean and 75th percentile values. Median revenue increased from $\$ 4,900$ in 1981 to $\$ 32,600$ in 2012 . Mean revenue declined from $\$ 98,000$ in 1981 to $\$ 51,000$ in 1985 , largely due to the departure of tuna super seiners earning multi-million dollar revenues, and increased to new highs in 2009-12 (\$115,000-129,000). The increasing revenue trend reflects the effects of greater opportunity in some fisheries as well as the exit of lower-revenue vessels over time. ${ }^{?}$

\section{Vessel Behavior by Region}

Table 4 describes California vessels by "principal region" (i.e., the region accounting for the plurality of the vessel's annual revenue) in terms of average annual number of vessels and average annual trips, landings, and revenues per vessel. Regional boundaries are the same as shown in Figure 8. Participation is consistently higher for North Central California than other regions, largely due to the concentration of salmon trollers in that region. Landings and revenue per vessel are influenced by the number of vessels in each region that participate in high-volume and high-revenue fisheries. Thus, for instance, high landings per boat in Southern and South Central California are affected by the concentration of CPS and squid seiners in these regions. Revenue per boat has generally been higher in 2006-10 and 2011-12 than in previous time intervals in all regions except Southern California. Due to the dominance of the tuna seine fishery in Southern California in the early 1980 's, revenue per boat in that region was much higher in 1981-85 than in subsequent years.

\section{Geographic Mobility and Fishery Diversification}

Geographic mobility and fishery diversification are important risk reduction strategies (Kasperski and Holland, 2013) and reflect the ability of vessels to adapt to restrictions in a particular area or fishery (Mason et al., 2012). Geographic mobility is characterized here in terms of whether each California vessel earned all of its annual revenue in 1) a single California port, 2)

\footnotetext{
${ }^{9}$ Although economic profit or net revenue per vessel are more meaningful indicators of economic benefits to the fleet than gross revenues, such indicators are not provided here due to the lack of cost data for most of the fisheries covered in this paper.
} 
more than one port but a single region, 3) two adjacent regions, or 4) more dispersed areas-i.e., two non-adjacent regions or more than two regions, including out of state. The relative distribution of vessels across mobility categories has remained fairly constant over time, averaging 58\%, 22\%, 14\%, and 6\% during 1981-2012 for categories 1 through 4, respectively. Figure 12 describes trends in average annual revenue per vessel for each mobility category during 1981-2012. Comparisons of revenue per vessel across mobility categories suggest that geographic mobility generally tends to enhance revenue opportunities. Average revenue does not exhibit any particular pattern over time for vessels in mobility categories 1 and 2 but has increased significantly over time for vessels in mobility categories 3 and 4 .

Figure 8 depicts the geographic distribution of California vessels in mobility categories 1 through 3 during 2011-12. The number next to each port pertains to the average annual number of boats who fished exclusively in that port in 2011-12, the number next to each region pertains to the number of vessels that fished in multiple ports but exclusively in that region, and the numbers connecting adjacent regions pertain to the number of boats who fished exclusively in the two connected regions. Only mobility categories involving at least three vessels are depicted.

Fishery diversification is analyzed in terms of whether each vessel earned all of its annual revenue in one fishery, two fisheries, or more than two fisheries. The percent of vessels falling in each diversification category during 1981-2012 was 50-63\% for one fishery, 23-31\% for two fisheries, and $10-23 \%$ for more than two fisheries. Figure 13 describes trends in average annual revenue per vessel for each diversification category during 1981-2012.

Generally speaking, diversification tends to enhance revenue opportunities. One notable exception: vessels that participated in two fisheries during 2006-10 and 2011-12 tended on aver-

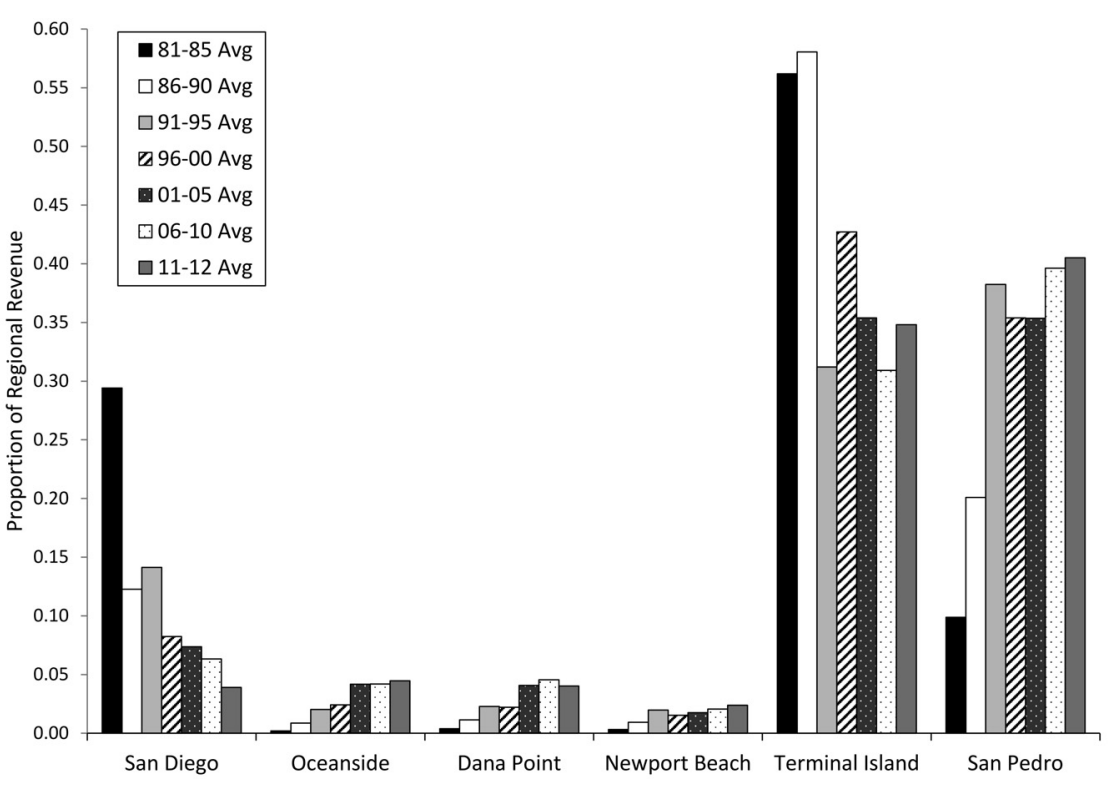

Figure 9a.-Average annual distribution of Southern California fishery revenues among ports (San Diego, Oceanside, Dana Point, Newport Beach, Terminal Island, San Pedro), 1981-2012 by time interval.

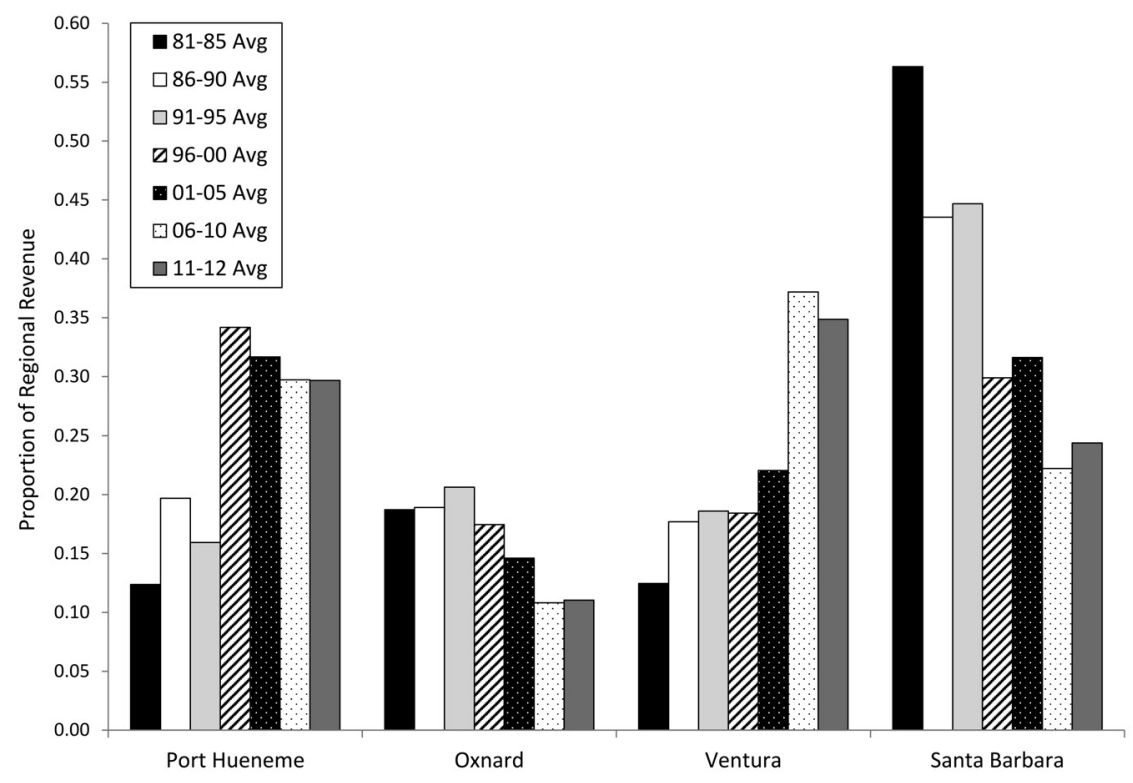

Figure 9b.-Average annual distribution of South Central California fishery revenues among ports (Port Hueneme, Oxnard, Ventura, Santa Barbara), 1981-2012 by time interval. 


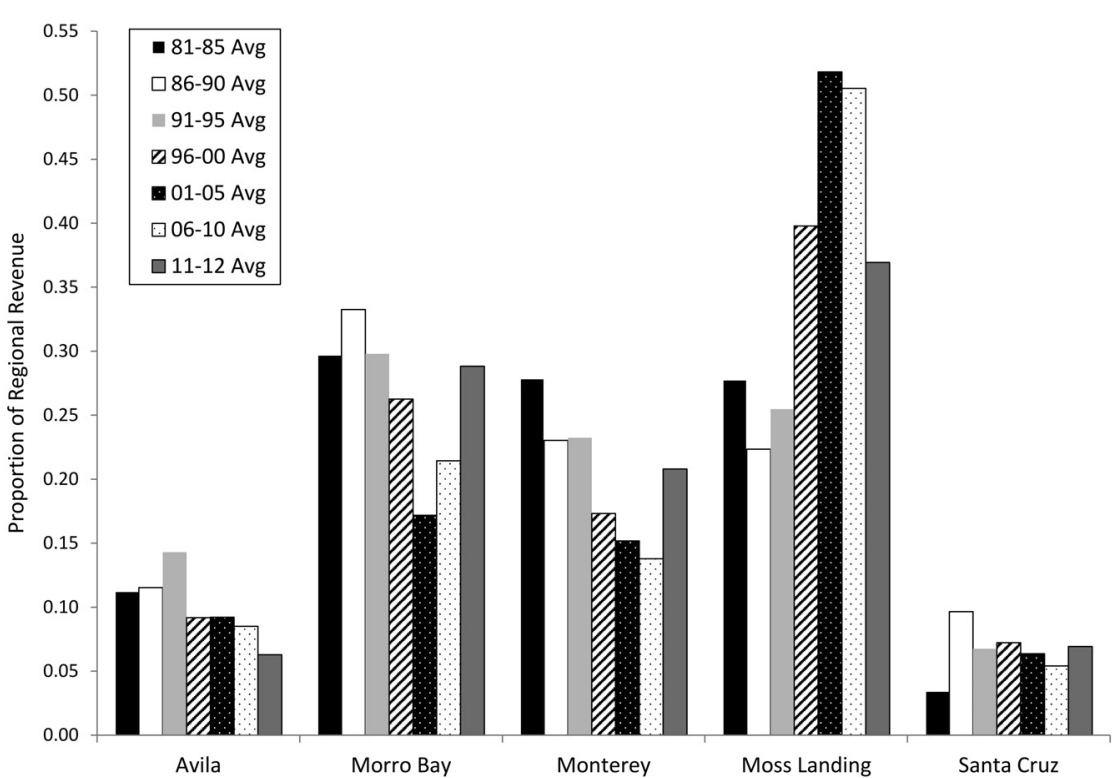

Figure 9c.-Average annual distribution of Central California fishery revenues among ports (Avila, Morro Bay, Monterey, Moss Landing, Santa Cruz), 1981-2012 by time interval.

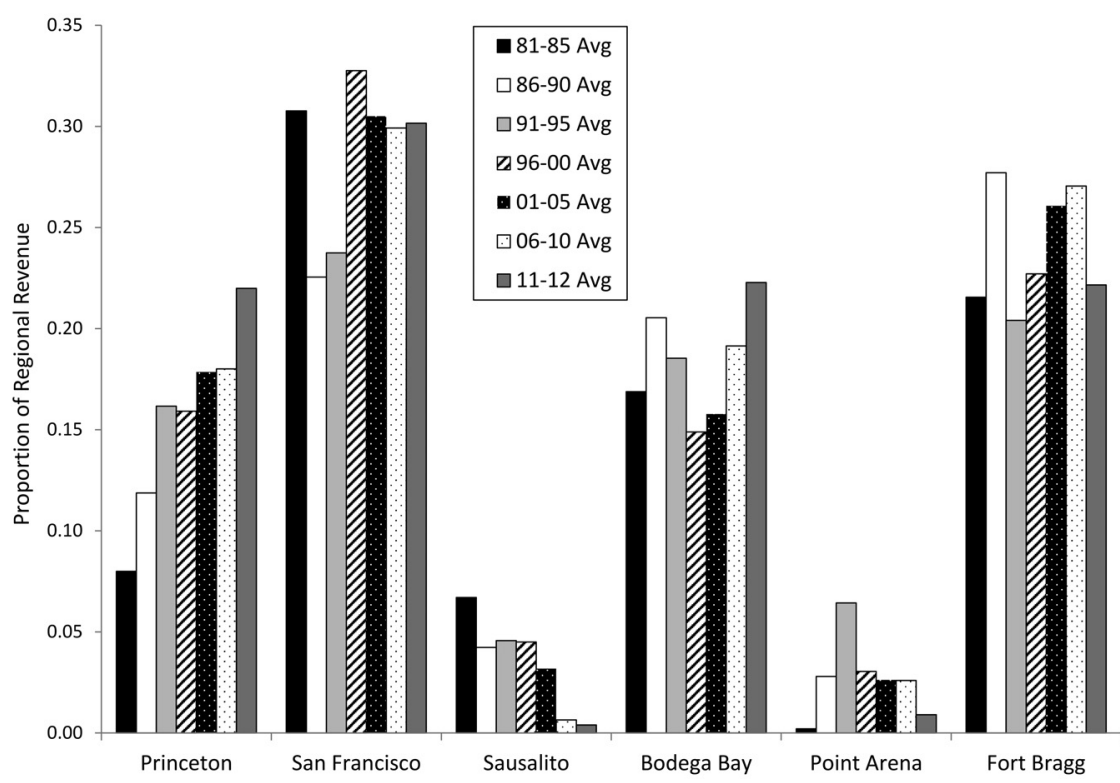

Figure 9d.-Average annual distribution of North Central California fishery revenues among ports (Princeton, San Francisco, Sausalito, Bodega Bay, Point Arena, Fort Bragg), 1981-2012 by time interval. age to have higher revenues than vessels who participated in more than two fisheries. The proportion of two-fishery vessels earning less than $\$ 25,000$ fell from 49\% during 1981-2005 to $34 \%$ during 2005-12, while the proportion earning more than $\$ 500,000$ per year more than tripled from 3\% to $10 \%$. For vessels that participated in more than two fisheries, the proportion earning less than $\$ 25,000$ and more than $\$ 500,000$ moved in the same direction as the two-fishery vessels, but the change between periods consisted of only a few percentage points.

For the two most recent years, 2011-12, an average annual 1,733 vessels earned the plurality of their revenue from California landings. Of these vessels, 51\% participated in one fishery, $31 \%$ in two fisheries, and $18 \%$ in more than two fisheries. Figure 14 highlights the most common one- and two-way fishery combinations employed by California vessels. The number in each box is the average annual number of boats who fished exclusively in that fishery in 2011-12, and the number connecting any two boxes is the average annual number of boats who fished exclusively in the two paired fisheries.

Table 5 highlights the most common ( $>3$ boats) three-way fishery combinations pursued by California vessels in 2011-12. Diversification most commonly involves fisheries utilizing the same gear or combinations of line and pot gear. Salmon troll, groundfish fixed gear, and Dungeness crab pot are particularly notable - not only in terms of the number of vessels that participate exclusively in each of these fisheries but also the frequency with which they are pursued in combination with other fisheries.

Table 6 focuses on California vessels whose principal fishery was Dungeness crab pot, salmon troll, groundfish fixed gear, lobster pot, urchin dive, or squid seine in 2011 and/or 2012. "Principal fishery" is defined here as the fishery accounting for the plurality of the vessel's annual revenue. The principal fisheries included here are those accounting for the largest number of 


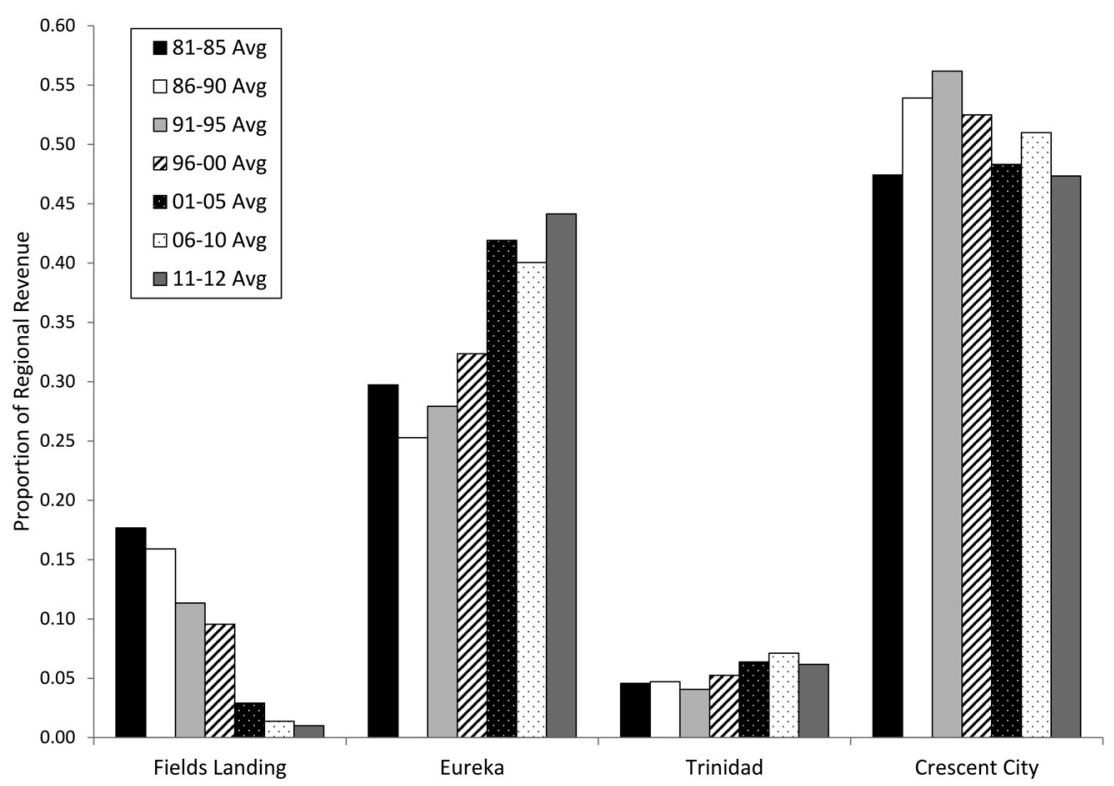

Figure 9e.-Average annual distribution of Northern California fishery revenues among ports (Fields Landing, Eureka, Trinidad, Crescent City), 1981-2012 by time interval. boats in 2011-12. Table 6 describes the average annual number of boats associated with each principal fishery, mean and median revenue per boat, and the relative distribution of boats among geographic and fishery diversification categories. Revenue per boat pertains to the boat's earnings in all fisheries (not just its principal fishery). Revenue is highest for boats whose principal fishery is squid seine or Dungeness crab pot and lowest for salmon troll and groundfish fixed gear. Affinity for a single port or a single fishery is strongest for boats whose principal fishery is groundfish fixed gear or urchin dive, while fishery diversification is highest for Dungeness crab pot. It is important to note that Table 6 focuses only on two recent years and that revenue and diversification patterns have changed over time. For example, the proportion of one-port vessels whose

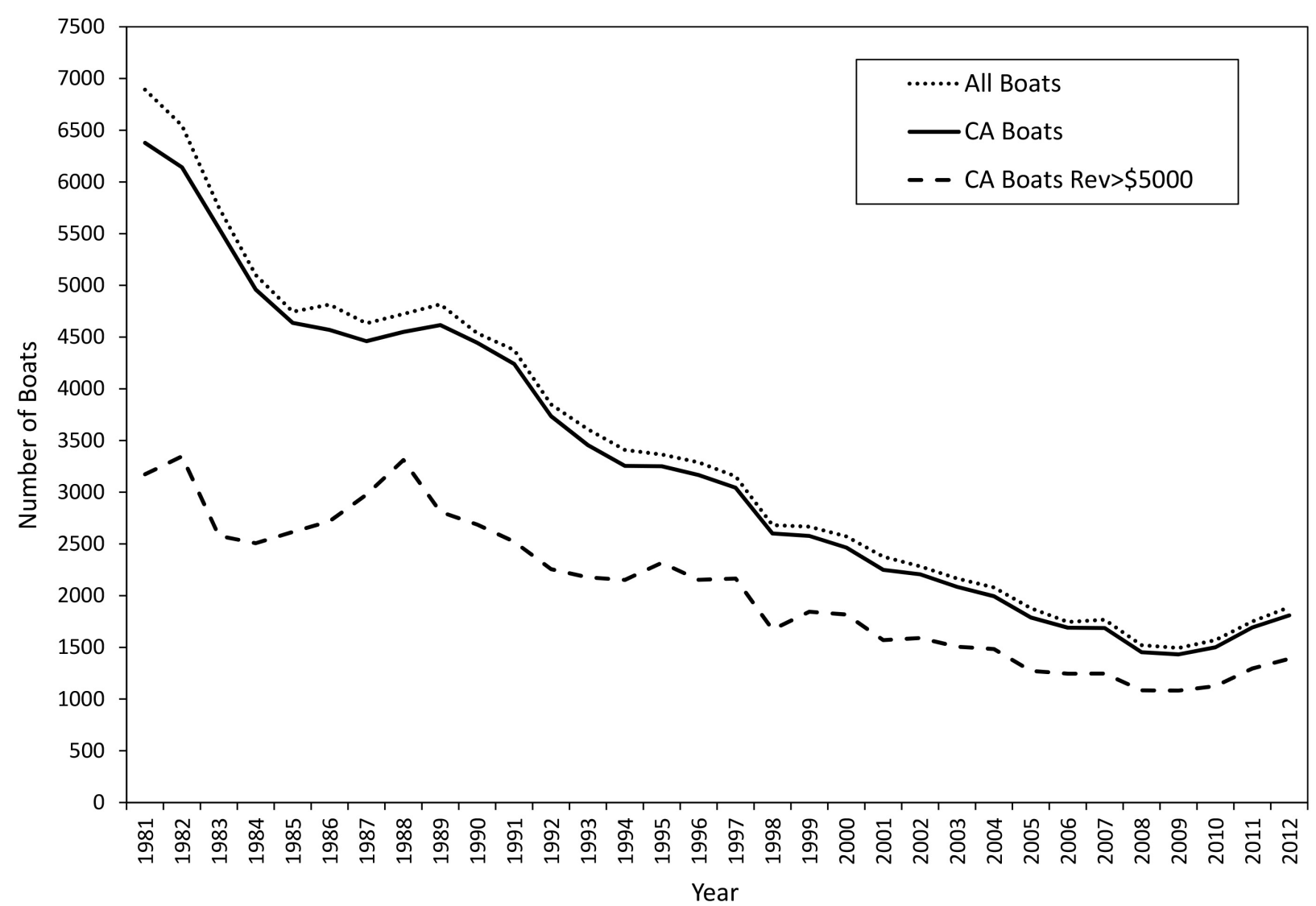

Figure 10.-Number of boats that participated in California fisheries (all boats), number of boats that earned the plurality of their revenue from California fisheries (CA Boats), and number of California boats that earned at least $\$ 5,000$ in annual revenue (CA Boats Rev>\$5,000), 1981-2012. 


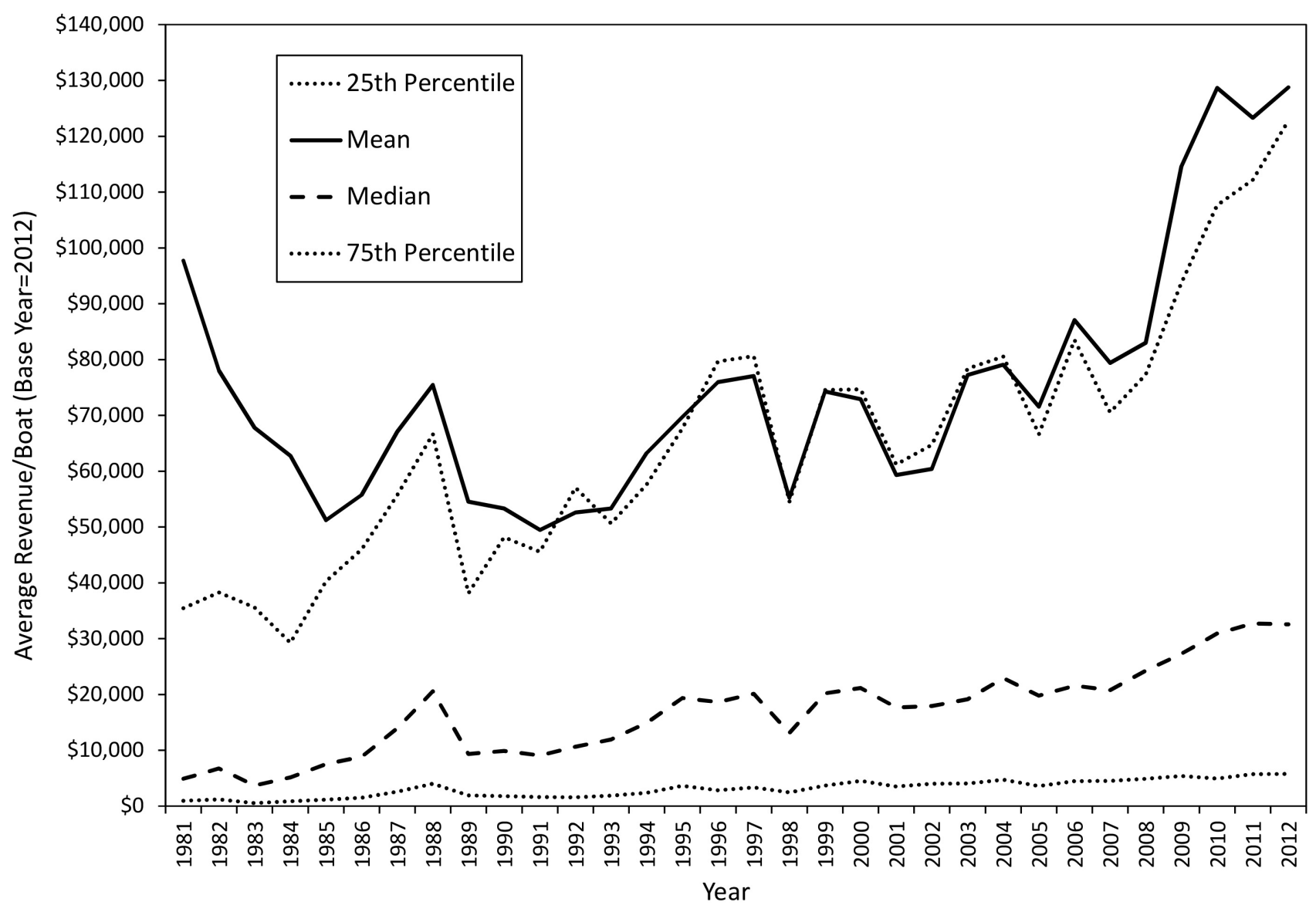

Figure 11.-Annual revenue per boat for California boats - mean, median, and 25th and 75th percentile values, 1981-2012. "California boats" are boats that earned the plurality of their annual revenue from California fisheries.

Table 4. - Number of boats and average annual trips, landings $(1,000$ s of pounds landed weight) and revenue $\left(\$ 1,000\right.$ s, base year=2012) per boat, 1981-2012, by principal region ${ }^{1}$ and time interval.

\begin{tabular}{|c|c|c|c|c|c|c|c|c|}
\hline & $\begin{array}{c}1981-2012 \\
\text { Avg }\end{array}$ & $\begin{array}{c}1981-85 \\
\text { Avg }\end{array}$ & $\begin{array}{c}1986-90 \\
\text { Avg }\end{array}$ & $\begin{array}{c}\text { 1991-95 } \\
\text { Avg }\end{array}$ & $\begin{array}{c}\text { 1996-2000 } \\
\text { Avg }\end{array}$ & $\begin{array}{c}2001-05 \\
\text { Avg }\end{array}$ & $\begin{array}{c}2006-10 \\
\text { Avg }\end{array}$ & $\begin{array}{c}2011-12 \\
\text { Avg }\end{array}$ \\
\hline \multicolumn{9}{|c|}{ Southern California } \\
\hline \#Boats & 631 & 1,163 & 761 & 628 & 546 & 438 & 360 & 358 \\
\hline Trips/Boat & 35 & 21 & 30 & 34 & 38 & 41 & 41 & 43 \\
\hline Landings/Boat & 345 & 302 & 274 & 219 & 365 & 361 & 467 & 553 \\
\hline Revenue/Boat & 127 & 218 & 126 & 76 & 111 & 92 & 122 & 171 \\
\hline \multicolumn{9}{|c|}{ South Central California } \\
\hline \#Boats & 355 & 406 & 416 & 467 & 375 & 261 & 247 & 249 \\
\hline Trips/Boat & 41 & 30 & 36 & 40 & 42 & 48 & 46 & 44 \\
\hline Landings/Boat & 309 & 99 & 146 & 149 & 370 & 425 & 567 & 560 \\
\hline Revenue/Boat & 107 & 52 & 78 & 97 & 109 & 107 & 167 & 188 \\
\hline \multicolumn{9}{|l|}{ Central California } \\
\hline \#Boats & 629 & 965 & 839 & 798 & 598 & 415 & 260 & 379 \\
\hline Trips/Boat & 24 & 19 & 25 & 24 & 26 & 24 & 26 & 27 \\
\hline Landings/Boat & 114 & 59 & 55 & 61 & 91 & 161 & 258 & 115 \\
\hline Revenue/Boat & 44 & 32 & 40 & 34 & 44 & 47 & 56 & 62 \\
\hline \multicolumn{9}{|c|}{ North Central California } \\
\hline \#Boats & 1,238 & 2,108 & 2,059 & 1,304 & 944 & 770 & 492 & 622 \\
\hline Trips/Boat & 22 & 17 & 23 & 23 & 24 & 23 & 22 & 23 \\
\hline Landings/Boat & 48 & 32 & 42 & 53 & 62 & 47 & 44 & 71 \\
\hline Revenue/Boat & 52 & 29 & 42 & 45 & 52 & 53 & 65 & 116 \\
\hline \multicolumn{9}{|l|}{ Northern California } \\
\hline \#Boats & 506 & 1,134 & 636 & 502 & 383 & 258 & 247 & 192 \\
\hline Trips/Boat & 28 & 25 & 30 & 28 & 30 & 29 & 29 & 28 \\
\hline Landings/Boat & 147 & 58 & 111 & 139 & 158 & 182 & 222 & 173 \\
\hline Revenue/Boat & 116 & 52 & 93 & 104 & 108 & 132 & 159 & 236 \\
\hline
\end{tabular}

1 "Principal region" defined as the region accounting for the plurality of a boat's annual revenue. principal fishery was salmon troll was considerably higher in $1981-83(52 \%)$ than 2011-12 (14\%), a trend related to the exit of many vessels from that fishery. The Dungeness crab fishery experienced record high revenues in 2012, and squid revenues in 2011-12 were exceeded only in 2010.

Geographic and fishery diversification are affected by a variety of factors, including the spatial distribution of target species, prices and constraints on entry in alternative fisheries, location of processors and other fisheryrelated businesses, fuel costs, vessel seaworthiness, ability of vessel and crew to adapt to alternative fisheries, regulations, and personal preference. The relatively low revenues earned by salmon trollers and groundfish fixed gear boats suggest that fishing is not 


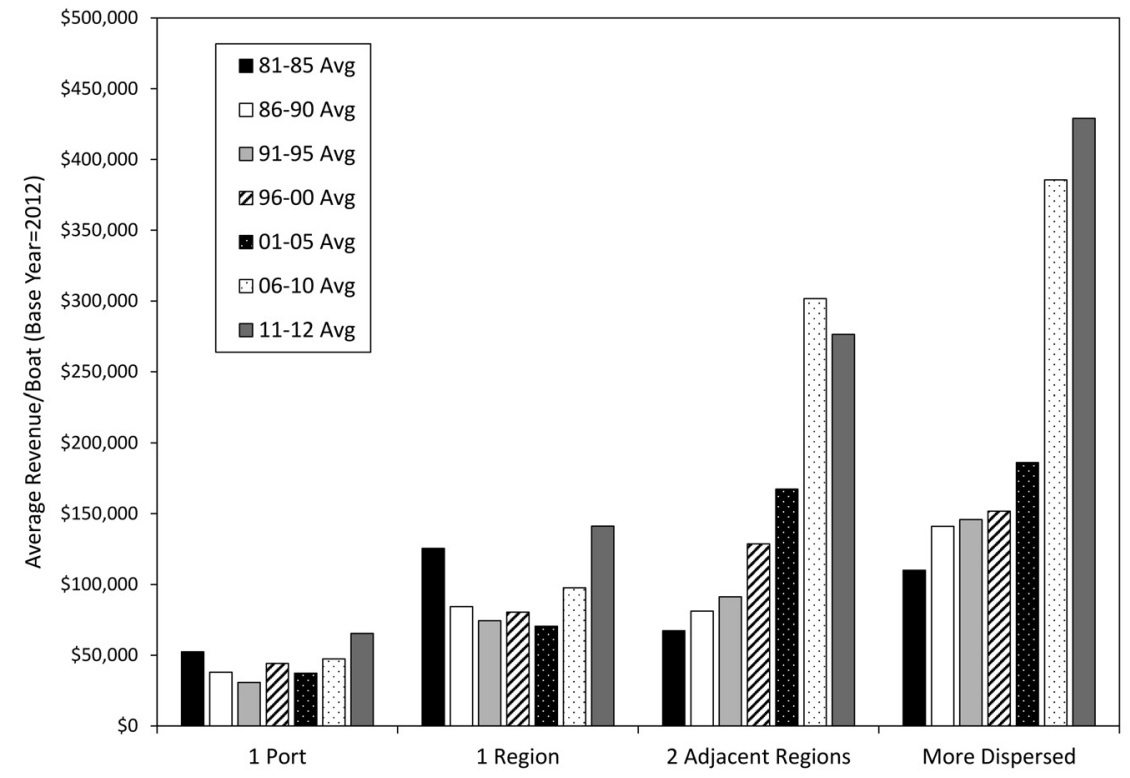

Figure 12.-Average annual revenue per boat for California boats, 1981-2012, by geographic mobility category and time interval. Mobility categories (based on regions described in Figure 8): 1 Port=landings occurred exclusively in one port, 1 Region=landings occurred in multiple ports in a single region, 2 Adjacent Regions=landings occurred exclusively in two adjacent regions, and More Dispersed=landings dispersed between two non-adjacent regions or more than two regions, including out of state.

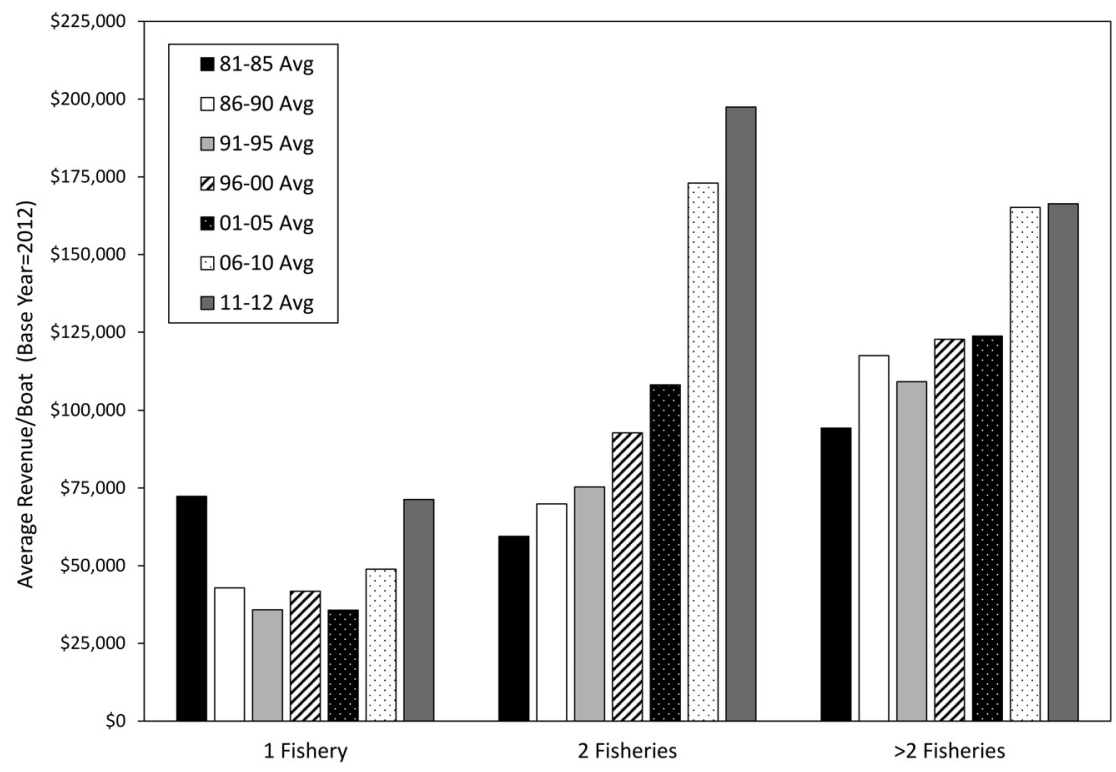

Figure 13.-Average annual revenue per boat for California boats, 1981-2012, by fishery diversification category and time interval. Fishery diversification categories $(1,2,>2)$ pertain to the number of fisheries in which a vessel participated during the year. the only source of income for many of these boats; however, the extent of their non-fishing income is not known.

\section{Conclusions}

Trends in California vessel participation, landings, and revenues varydepending on the particular fishery, time frame, and geographic area considered. For instance, the statewide landings trend dating from 1981 indicates that landings peaked in the early 1980's and have been considerably lower (though quite variable) in subsequent years (Fig. 4). By contrast, the landings trend dating from 1916 suggests even greater variability in landings and a much larger decline in recent years relative to the earlier years of that time series (Fig. 1).

Expansions and contractions of seafood markets (global as well as domestic) provide new opportunities and vulnerabilities for California fisheries. Changes in ex-vessel prices experienced in recent decades (e.g., positive for groundfish fixed gear, lobster pot, and salmon troll, negative for swordfish drift gillnet and sea urchin) and the recent reemergence of the hagfish pot fishery illustrate the influence of market conditions on fisheries. Factors such as technology, fuel prices, fishery infrastructure, labor availability, and regulatory compliance costs have also changed over time.

Past trends can provide clues to the future. However, historic lows (e.g., 1950's collapse of the sardine fishery, 2008-10 salmon landings) and highs (e.g., 1988 salmon landings, 2011-12 Dungeness crab and squid landings) do not always serve as relevant reference points for identifying current management problems or shaping expectations regarding long-term harvest opportunities. For many fisheries, regulations have become much more constraining on harvest and effort in recent decades. Harvests also vary for reasons beyond the control of managers. Environmental conditions can affect stock abundance and distribution in sometimes pronounced ways; notable examples of this have become apparent even in the few years since 2012 
(the last year of the quantitative analysis provided in this paper). ${ }^{10}$ Research that systematically considers physical, biological, and economic factors in an ecosystem framework (Field et al., 2006; Norton et al., 2013) is important for understanding the complexity and interrelatedness of California fisheries.

Participation, landings, and revenue trends alone are a simplistic and sometimes misleading basis for judging management performance. Fishery declines can occur as a result of effective management as well as belated, ineffective, or nonexistent management. Stock abundance goes up and down for a variety of reasons; an important management responsibility is to ensure that harvest restrictions are responsive to stock dynamics, regardless of their cause. Changes in legislative mandates and scientific information can precipitate changes in management. Judgments regarding management performance should be made in the context of the system that produced those decisions. Relevant system features include whether the management process is based on best

\footnotetext{
${ }^{10}$ Since 2012 , sardine abundance, which is affected by ocean conditions as well as fishing mortality (Deyle et al., 2013; CDFW, 2015), has declined precipitously in Oregon and Washington as well as California. California sardine landings are now lower than they have been since 1990, and northern anchovy is now the largest (albeit still modest) component of CPS finfish catch (PFMC, 2014b). Squid landings in 2015 were the lowest since 1998, and strong El Niño conditions do not bode well for this fishery in 2016. These changes indicate poor economic prospects for California's wetfish harvesters and processors, for whom sardine and squid are traditional mainstays. Dungeness crab landings plummeted in 2015 due to a large and persistent domoic acid bloom associated with El Niño. The public health risk prompted CDFW to close the fishery by emergency regulation in November 2015 , before the peak holiday demand period (OAL. 2015. Notice of Approval of Emergency Regulatory Action. Off. Admin. Law, State of Calif. OAL Matter Number 2016-1106-04, Nov. 6, 2015, http://www.oal.ca.gov/res/docs/pdf/ emergencies/recent $\% 20$ action, $\% 20$ moved $\% 20$ emergencies/Fish $\% 20$ and $\% 20$ Wildlife $\% 20$ 2015-1106-04E\%20Approval.pdf (accessed 18 Feb. 2016)).

The salmon troll fishery rebounded in 2013, with landings at 2005 levels and revenues the second highest experienced since 1990. However, persistent drought conditions and associated concerns regarding the status of endangered Sacramento River winter Chinook have since constrained the fishery (CDFW, 2015).
}

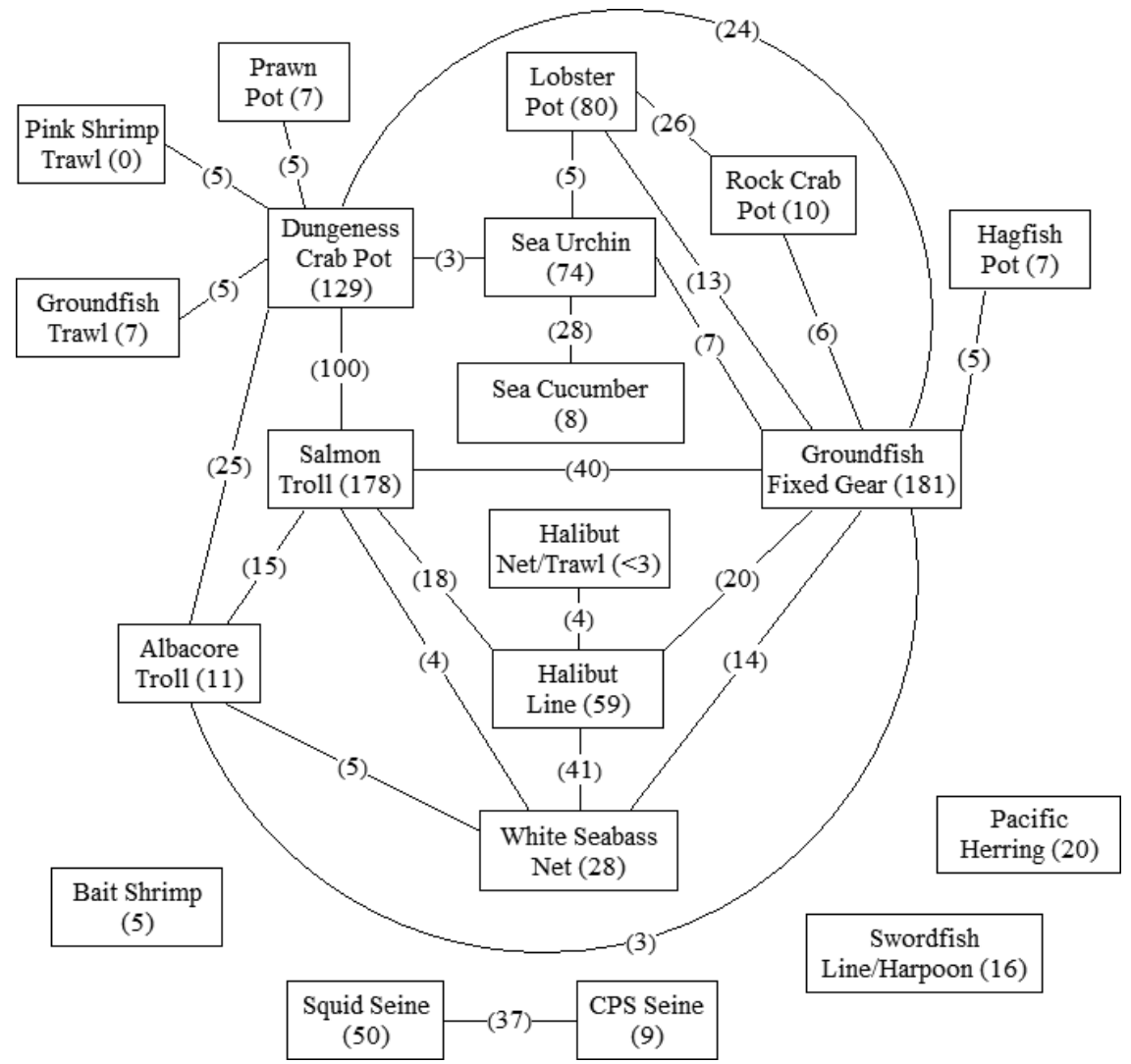

Figure 14.- Average annual number of California boats participating in most common one- and two-way fishery combinations, 2011-12. available science, provides adequate opportunity for public input, reflects consideration of uncertainty, adapts appropriately to changing states of the fishery (e.g., developing, fully exploited, overexploited, rebuilding), and ensures accountability through appropriate incentives and monitoring and enforcement. Retrospective analyses are instructive for evaluating the extent to which major fishery management actions achieve their objectives.
Evidence from California fisheries suggests that fishery diversification and geographic mobility enhance revenue. One way to encourage such flexibility would be to provide fishermen with greater operational discretion within the confines of management objectives. This may involve, for instance, tailoring regulations so that they do not unduly constrain fleet mobility or industry efforts at gear and product innovation, or making per-
Table 5. - Most common ( $>3$ boats) three-way fishery combinations employed by California boats in 2011-12 and average annual number of boats employing each combination.

\begin{tabular}{lllc}
\hline & Three-way fishery combinations & & \# boats \\
\hline Dungeness crab pot & Salmon troll & Albacore troll & 34 \\
Dungeness crab pot & Salmon troll & Groundfish fixed gear & 29 \\
Groundfish fixed gear & Halibut line & White seabass gillnet & 21 \\
Rock crab pot & Lobster pot & Groundfish fixed gear & 11 \\
Halibut line & White seabass gillnet & Albacore troll & 10 \\
Halibut line & White seabass gillnet & Salmon troll & 9 \\
Groundfish fixed gear & Salmon troll & Albacore troll & 8 \\
Groundfish fixed gear & Salmon troll & White seabass gillnet & 5 \\
Dungeness crab pot & Salmon troll & Halibut line & 4 \\
\hline
\end{tabular}


Table 6. - Number of California boats by principal fishery ${ }^{1}$, mean and median revenue per boat from all fisheries $(\$ 1,000$ s, base year=2012), and relative distribution of boats among geographic and fishery diversification categories, 2011-12 average. Principal fisheries selected for inclusion in this table are those accounting for the largest number of boats in 2011-12.

\begin{tabular}{|c|c|c|c|c|c|c|c|}
\hline & $\begin{array}{c}\text { All } \\
\text { boats }\end{array}$ & $\begin{array}{l}\text { Dungeness } \\
\text { crab pot }\end{array}$ & $\begin{array}{l}\text { Salmon } \\
\text { troll }\end{array}$ & $\begin{array}{l}\text { Groundfish } \\
\text { fixed gear }\end{array}$ & $\begin{array}{c}\text { Lobster } \\
\text { pot }\end{array}$ & $\begin{array}{l}\text { Urchin } \\
\text { dive }\end{array}$ & $\begin{array}{l}\text { Squid } \\
\text { seine }\end{array}$ \\
\hline \# boats & 1,751 & 381 & 288 & 272 & 159 & 104 & 100 \\
\hline Mean revenue & 126.0 & 198.4 & 19.5 & 46.3 & 91.0 & 81.0 & 733.1 \\
\hline Median revenue & 32.6 & 123.4 & 9.3 & 17.7 & 71.4 & 53.4 & 539.2 \\
\hline \multicolumn{8}{|c|}{ Vessel distribution across geographic diversification categories ${ }^{2}$} \\
\hline 1 port & 0.58 & 0.51 & 0.57 & 0.73 & 0.53 & 0.68 & 0.37 \\
\hline 1 region & 0.24 & 0.28 & 0.17 & 0.18 & 0.42 & 0.26 & 0.13 \\
\hline 2 adjacent regions & 0.14 & 0.18 & 0.22 & 0.06 & 0.03 & 0.03 & 0.31 \\
\hline More dispersed & 0.04 & 0.03 & 0.04 & 0.03 & 0.02 & 0.03 & 0.19 \\
\hline \multicolumn{8}{|c|}{ Vessel distribution across fishery diversification categories ${ }^{3}$} \\
\hline 1 fishery & 0.52 & 0.34 & 0.62 & 0.68 & 0.50 & 0.70 & 0.50 \\
\hline 2 fisheries & 0.30 & 0.39 & 0.22 & 0.21 & 0.29 & 0.26 & 0.43 \\
\hline$>2$ fisheries & 0.18 & 0.27 & 0.16 & 0.11 & 0.21 & 0.04 & 0.07 \\
\hline
\end{tabular}

${ }^{2}$ Based on ports and regions depicted in Figure 8: 1 Port=landings occurred exclusively in one port, 1 Region=landings occurred in multiple ports in a single region, 2 Adjacent Regions=landings occurred exclusively in two adjacent regions. ${ }^{3}$ Fishery diversification categories $(1,2,>2)$ pertain to the number of fisheries in which a boat participated during the year.

mit programs flexible in ways that encourage entry of "new blood" into fisheries.

Another management tool that can increase operational flexibility is catch shares. Catch share programs are well known for curtailing the race for fish and enhancing the economic productivity of quota holders (Mamula and Collier, 2015); catch shares also encourage fleet consolidation which, in turn, leads to employment losses (Lian et al., 2009). An important consideration is finding an acceptable balance between efficiency gains and employment losses. Management measures often involve such trade-offs; there is rarely a universally "best" way to achieve any given management objective (Melnychuk et al., 2013).

Given the disparate distribution of vessels, landings, and revenues among fisheries, the effect of regulations on each of these indicators can vary widely-depending on which fisheries are targeted by such regulations. Patterns of movement among fisheries are instructive for anticipating the extent to which effort displaced from one fishery (whether due to management restrictions or adverse market or environmental conditions) is diverted to other fisheries. The distinctively regional nature of many California fisheries, the high proportion of vessels that land fish exclusively in one port $(58 \%)$ and one region $(22 \%)$ per year, and the high dependence on lo- infrastructure needs. Understanding community dynamics requires a better understanding of the port choices made by fishermen and infrastructure providers (including processors), the extent to which fisheries contribute to port revenues and costs, and strategies used by ports to cope with variability in fishing activity.

\section{Acknowledgments}

The support of the following individuals is gratefully acknowledged: Dave Colpo and PacFIN staff at the Pacific States Marine Fisheries Commission provided access to and advice regarding interpretation of landings receipt data. John Field, Rosemary Kosaka, and two anonymous reviewers provided insightful comments on earlier drafts of this paper. Rita Curtis (NMFS Office of Science and Technology, Economics and Social Analysis Division) provided funding that made this analysis possible.

\section{Literature Cited}

While a large proportion of California vessels fish in a single port, the extent to which such behavior is due to personal preference or to management or other constraints is not clear. The modest revenue earned by many of these boats (largely salmon trollers and groundfish fixed gear vessels) suggests that they may also have non-fishing income that buffers them against the vagaries of limited mobility. Landings and revenues tend to be considerably higher for more mobile operators-suggesting that they are more reliant on fishing as their major source of income.

Participation, landings, and revenue vary not only over time but also among regions (Table 2) and among ports within each region (Fig. 9ae)-reflecting localized differences in factors such as species availability, regulations, fishery infrastructure, and weather. To the extent that high-effort or high-volume fisheries influence the location of processing plants and other infrastructure, the presence of such fisheries in a port may also benefit smaller fisheries that have similar
Anderson, S. C., J. M. Flemming, R. Watson, and H. K. Lotze. 2011. Serial exploitation of global sea cucumber fisheries. Fish Fish. 12(3):317-339. (doi: https://doi.org/10.1111/ j.1467-2979.2010.00397.x).

California Department of Fish and Game (CDFG). 1990. Review of some California fisheries for 1989. CalCOFI Rep. 31:9-21. 2002. Nearshore fishery management plan. Calif. Dep. Fish Game, Calif. Fish Game Code $\$ \S 2850-2863$. 2005. Final market squid fishery management plan. Calif. Dep. Fish Game, Los Alamitos, Calif., 560 p.

2008. Review of some California fisheries for 2007: coastal pelagic finfish, market squid, Dungeness crab, California spiny lobster, highly migratory species, ocean salmon, groundfish, California halibut, hagfish, Pacific herring, and recreational. CalCOFI Rep. 49:15-38.

2012. Review of selected California fisheries for 2011: ocean salmon, California sheephead, California halibut, longnose skate, petrale sole, California spiny lobster, Dungeness crab, garibaldi, white shark, and algal blooms. CalCOFI Rep. 53:32-34.

California Department of Fish and Wildlife (CDFW). 2013. Review of selected California fisheries for 2012: coastal pelagic finfish, market squid, Pacific herring, groundfish, highly migratory species, white seabass, $\mathrm{Pa}$ cific halibut, red sea urchin, and sea cucumber. CalCOFI Rep. 54:12-36. 2015. Review of selected California fisheries for 2014: coastal pelagic finfish market squid, groundfish, Pacific herring, Dungeness crab, ocean salmon, true smelts, hagfish, and deepwater ROV surveys of 
MPAs and surrounding nearshore habitat. CalCOFI Rep. 56:1-30

Carretta, J. V., T. Price, D. Petersen, and R. Read. 2004. Estimates of marine mammal, sea turtle, and seabird mortality in the California drift gillnet fishery for swordfish and thresher shark, 1996-2002. Mar. Fish. Rev. $66(2): 21-30$.

Coe, J. M., D. B. Holts, and R. W. Butler. 1984. The "tuna-dolphin" problem: NMFS dolphin mortality reduction research, 1970-1981. Mar. Fish. Rev. 46(3):18-33.

DeReynier, Y. 2012. Making ecosystem-based management a reality: the Pacific Fishery Management Council and the California Current Integrated Ecosystem Assessment. CalCOFI Rep. 53:81-88.

Dewees, C. M., and M. L. Weber. 2001. A review of restricted access programs. In W. S. Leet, C. M. Dewees, R. Klingbeil, and E. J. Larson (Editors), California's living marine resources: a status report, p. 73-76. Calif. Dep. Fish Game, Sacramento.

Deyle, E. R., M. Fogarty, C. H. Hsieh, L. Kaufman, A. D. MacCall, S. B. Munch, C. T. Peretti, H. Ye, and G. Sugihara. 2013. Predicting climate effects on Pacific sardine. Proc. Natl. Acad. Sci. 110(6):6430-6435. (doi: https://doi.org/10.1073/pnas.1215506110).

FFITF. 1999. Federal Fisheries Investment Task Force Report to Congress. Prepared for NOAA under contract with Atl. States Mar. Fish. Comm., Arlington, Va, $229 \mathrm{p}$.

Field, J. C., R. C. Francis, and K. Aydin. 2006. Top-down modeling and bottom-up dynamics: linking a fisheries-based ecosystem model with climate hypotheses in the Northern California Current. Prog. Oceanogr. 68(2-4):238-270

Francis, R. C., F. T. Awbrey, C. A. Goudey, M. A. Hall, D. M. King, H. Medina, and K. S. Norris. 1992. Dolphins and the tuna industry. Natl. Acad. Press, Wash., D.C., 192 p.

French, R., R. Nelson Jr., and J. Wall. 1981. The foreign fisheries off Washington, Oregon, and California, 1977-78. Mar. Fish. Rev. 43(5):36-44.

Godsil, H. C. 1938. The high seas tuna fishery of California. Calif. Div. Fish Game, Fish Bull. 51, 41 p.

Haaker, P. L., K. Karpov, L. Rogers-Bennett, I. Taniguchi, C. S. Friedman, and M. J. Tegner. 2001. Abalone. In W. S. Leet, C. M. Dewees, R. Klingbeil, and E. J. Larson (Editors), California's living marine resources: a status report, p. 89-96. Calif. Dep. Fish Game, Sacramento.

Hankin, D., and R. W. Warner. 2001. Dungeness crab. In W. S. Leet, C. M. Dewees, R. Klingbeil, and E. J. Larson (Editors), California's living marine resources: a status report, p. 107-111. Calif. Dep. Fish Game, Sacramento.

Hannah, R. W., and S. A. Jones. 2007. Effectiveness of bycatch reduction devices (BRDs) in the ocean shrimp (Pandalus jordani) trawl fishery. Fish. Res. 85(1-2):217-225. (doi: https://doi.org/10.1016/j.fishres.2006.12.010).

Herrick, S. F., Jr., K. Hill and C. Reiss. 2006. An optimal harvest policy for the recently renewed United States Pacific sardine fishery. In R. Hannesson, M. Barange, and S. F. Herrick, Jr. (Editors), Climate change and the economics of the world's fisheries - examples of small pelagic stocks, p. 126-150. Edward Elgar Publ., Inc: Cheltenham, U.K. (doi: https://doi.org/10.4337/9781845428846 $.00010)$.

Hilborn, R., I. J. Stewart, T. A. Branch, and O. P. Jensen. 2011. Defining trade-offs among conservation, profitability, and food security in the California Current bottom-trawl fishery. Conserv. Biol. 26(2):257-266. (doi: https:// doi.org/10.1111/j.1523-1739.2011.01800.x).

Hill, K. T., P. R. Crone, D. A. Demer, J. Zwolinski, E. Dorval, and B. J. Macewicz. 2014 Assessment of the Pacific sardine resource in 2014 for U.S.A. management in 2014-15. U.S. Dep. Commer., NOAA Tech. Memo. NOAA-TM-NMFS-SWFSC-531, $183 \mathrm{p}$.

Jacobson, L., and C. J. Thomson. 1993. Opportunity costs and the decision to fish for northern anchovy. N. Am. J. Fish. Manage. 13(1):27-34.

Jacobson, L. D., and S. McClatchie. 2013. Comment on temperature-dependent stock-recruit modeling for Pacific sardine (Sardinops sagax) in Jacobson and MacCall (1995), McClatchie et al. (2010), and Lindegren and Checkley (2013). Can. J. Fish. Aquat. Sci. 70(10):1566-1569. (doi: https://doi. org/10.1139/cjfas-2013-0128).

Kalvass, P., and L. Rogers-Bennett. 2001. Red sea urchin. In W. S. Leet, C. M. Dewees, R. Klingbeil, and E. J. Larson (Editors), California's living marine resources: a status report, p. 101-104. Calif. Dep. Fish Game, Sacramento.

Kasperski, S., and D. S. Holland. 2013. Income diversification and risk for fishermen. Proc. Natl. Acad. Sci. 110(6):2076-2081.

Knaggs, E. H. 1973. San Pedro wetfish fleet: major purse-seine gear changes, 1952-1972. Commer. Fish. Rev. 34:10-32.

Knapp, G., C. A. Roheim, and J. L. Anderson. 2007. The great salmon run: competition between wild and farmed salmon. TRAFFIC N. Am., World Wildl. Fund, Wash., D.C., 302 p.

Koslow, J. A., and C. Allen. 2011. The influence of the ocean environment on the abundance of market squid, Doryteuthis (loligo) opalescens, paralarvae in the Southern California Bight. CalCOFI Rep. 52:205-213.

Leet, W. S., C. M. Dewees, R. Klingbeil, and E. J. Larson (Editors). 2001. California's living marine resources: a status report. Calif. Dep. Fish Game, Sacramento, 593 p.

Levine, A., and S. Allen. 2009. American Samoa as a fishing community. U.S. Dep. Commer. NOAA Tech. Memo. NOAA-TM-NMFS-PIF$\mathrm{SC}-19,74 \mathrm{p}$

Lian, C., R. Singh, and Q. Weninger. 2009. Fleet restructuring, rent generation, and the design of individual fishing quota programs: empirical evidence from the $\mathrm{Pa}$ cific Coast groundfish fishery. Mar. Res. Econ. 24(4):329-359. (doi: https://doi. org/10.5950/0738-1360-24.4.329).

Lindgren, M., and D. M. Checkley Jr. 2013. Temperature dependence of Pacific sardine (Sardinops sagax) recruitment in the California Current Ecosystem revisited and revised. Can. J. Fish. Aquat. Sci. 70(2):245-252. (doi https://doi.org/10.1139/cjfas-2012-0211).

Lindley, S. T., C. B. Grimes, M. S. Mohr, W. Peterson, J. Stein, J. T. Anderson, L. W. Botsford, D. L. Bottom, C. A. Busack, T. K. Collier, J. Ferguson, J. C. Garza, A. M. Grover, D. G. Hankin, R. G. Kope, P. W. Lawson, A. Low, R. B. MacFarlane, K. Moore, M. Palmer-Zwahlen, F. B. Schwing, J. Smith, C. Tracy, R. Webb, B. K. Wells, and T. H. Williams.
2009. What caused the Sacramento River fall Chinook stock collapse? U.S. Dep. Commer., NOAA Tech. Memo. NOAA-TM-NMFSSWFSC-447, $61 \mathrm{p}$.

Lyons, K., E. T. Jarvis, S. J. Jorgensen, K. Weng, J. O'Sullivan, C. Winkler, and C. G. Lowe. 2013. The degree and result of gillnet fishery interactions with juvenile white sharks in southern California assessed by fishery-independent and -dependent methods. Fish. Res 147:270-280. (doi: https://doi.org/10.1016/j. fishres.2013.07.009).

MacCall, A. D. 1996. Patterns of low-frequency variability in fish populations of the California Current. CalCOFI Rep. 37:100-110.

Mamula, A. and T. Collier. 2015. Multifactor productivity, environmental change, and regulatory impacts in the U.S. west coast groundfish trawl fishery, 1994-2013. Mar. Pol. 62:326-336. (doi: https://doi.org/10.1016/j. marpol.2015.06.002)

Mansfield, B. 2001. Property regime or development policy? Explaining growth in the U.S Pacific groundfish fishery. Professional Geog. 53(3):384-397.

Mantua, N. J., S. R. Hare, Y. Zhang, J. M. Wallace and R. C. Francis. 1997. A Pacific interdecadal climate oscillation with impacts on salmon production. Bull. Am. Meteorol. Soc. 78(6):1069-1079. (doi: https://doi. org/10.1175/1520-0477(1997)078<1069:API $\mathrm{COW}>2.0 . \mathrm{CO} ; 2$ )

Marr, J. C. 1960. The causes of major variations in the catch of Pacific sardine. In $\mathrm{H}$. Rosa and G. Murphy (Editors), Proceedings of the world scientific meeting on the biology of sardines and related species, p. 667-791. F.A.O., Rome, Italy

Mason, J. E. 2004. Historical patterns from 74 years of commercial landings from California waters. CalCOFI Rep. 45:180-190.

R. Kosaka, A. Mamula, and C. Speir 2012. Effort changes around a marine reserve: the case of the California Rockfish Conservation Area. Mar. Pol. 36(5):1054 1063. (doi: https://doi.org/10.1016/j.marpol. 2012.03.002).

Maunder, M. N., and A. E. Punt. 2004. Standardizing catch and effort data: a review of recen approaches. Fish. Res. 70:141-159. (doi: https://doi.org/10.1016/j.fishres.2004.08.002)

McEvoy, A. F. 1986. The fisherman's problem: ecology and law in the California fisheries, 1850-1980. Camb. Univ. Press, Camb., 368

Melnychuk, M. C., J. A. Banobi, and R. Hilborn. 2013. Effects of management tactics on meeting conservation objectives for Western North American groundfish fisheries. PLOS ONE. 8(2):1-15. (doi: https://doi.org/10.1371/journal.pone.0056684).

Methot, R. D., Jr., G. R. Tromble, D. M. Lambert, and K. E. Greene. 2013. Implementing a science-based system for preventing overfishing and guiding sustainable fisheries in the United States. ICES J. Mar. Sci. 71: 183-194. (doi: https://doi.org/10.1093/icesjms/fst119).

MLMA. 1998. Marine life management act. $\mathrm{Ca}-$ lif. Fish Game Code $\$ \S 7050$ et seq.

MLPA. 1999. Marine Life Protection Act. Calif Fish Game Code $\S \S 2850-2863$.

MSFCMA. 1976. Magnuson-Stevens Fishery Conservation and Management Act. Public Law 94-297. 13 Apr. 1976. 16 U.S.C. $\S \S$ $1801-1882$ 
1996. Magnuson-Stevens Fishery Conservation and Management Act (Public Law 94-297) As Amended by the Sustainable Fisheries Act (P.L. 104-297). 11 Oct. 1996. 16 U.S.C. $\$ \S 1801-1857$.

2007. Magnuson-Stevens Fishery Conservation and Management Act (Public Law 94-297) As Amended by the Magnuson-Stevens Fishery Conservation and Management Reauthorization Act of 2007 (P.L. 109-479). 12 Jan. 12 2007. 16 U.S.C. $\S \S 1801$ et seq.

NMFS. 2004. The aftereffects of the Pacific groundfish limited entry trawl buyback program - a preliminary analysis. National Marine Fisheries Service, Northwest Region. PFMC April 2004 Briefing Book, Attachment C.17.b, Suppl. NMFS, 10 p. Pac. Fish. Manage. Counc., Portland, Oreg.

Norton, J. G., J. E. Mason, C. Bessey, and S. F. Herrick. 2013. Physical, biological and economic interconnections in the ecosystems and fisheries off California, 1877-2014. Quarternary Int. 310:7-19.

Orbach, M. K. 1977. Hunters, seamen, and entrepreneurs: the tuna seinermen of San Diego. Univ. Calif. Press, Berkeley, 304 p.

Perrin, W. F., and B. G. Noetzel. 1970. Economic study of the San Pedro wetfish boats. Fish. Ind. Res. 6(3):105-138.

PFMC. 1977. Final environmental impact statement for the implementation of a fishery management plan for commercial and recreational salmon fisheries off the coasts of Washington, Oregon, and California. Pac. Fish. Manage. Counc., Portland, Oreg., 103 p. 1978. Northern anchovy fishery final environmental impact statement and fishery management plan. Pac. Fish. Manage. Counc., Portland, Oreg., 317 p.

1984. First amendment and implementing regulations to the Pacific Coast groundfish fishery management plan incorporating the environmental assessment, the regulatory impact review/regulatory flexibility analysis, and requirements of other applicable law. Pac. Fish. Manage. Counc., Portland, Oreg., 79 p.

1992. Amendment 6 (Limited Entry) to the fishery management plan for pacific coast groundfish including supplemental environmental impact statement, regulatory impact review, and initial regulatory flexibility analysis. Pac. Fish. Manage. Counc., Portland, Oreg., 508 p.

1997. Amendment 12 to the fishery management plan for commercial and recreational salmon fisheries off the coasts of Washington, Oregon and California commencing in 1978 and amendment 10 to the Pacific Coast groundfish plan, incorporating the regulatory impact review, initial regulatory flexibility analysis and environmental assessment. Pac. Fish. Manage. Counc., Portland, Oreg., 153 p.

1998a. Amendment 8 (to the northern anchovy fishery management plan) incorporating a name change to: the coastal pelagic species fishery management plan. Pac. Fish. Manage. Counc., Portland, Oreg., $432 \mathrm{p}$.

1998b. Final environmental assessment/regulatory impact review for amendment 11 to the Pacific Coast groundfish fishery management plan. Pac. Fish. Manage. Counc., Portland, Oreg., 157 p.

2003. Fishery management plan and environmental impact statement for U.S. west coast fisheries for highly migratory species. Pac. Fish. Manage. Counc., Portland, Oreg. 2008a. Assessment of factors affecting natural area escapement shortfall of Klamath River fall Chinook salmon in 2004 2006. Pac. Fish. Manage. Counc., Portland, Oreg., 86 p.

2008b. Management of krill as an essential component of the California Current ecosystem-amendment 12 to the coastal pelagic species fishery management plan, environmental assessment, regulatory impact review and regulatory flexibility analysis. Pac. Fish. Manage. Counc., Portland, Oreg., $118 \mathrm{p}$.

2010a. Allocation of harvest opportunity between sectors of the Pacific Coast groundfish fishery-final environmental impact statement including regulatory flexibility review and initial regulatory flexibility analysis. Pac. Fish. Manage. Counc., Portland, Oreg., 280 p.

2010b. Rationalization of the Pacific Coast groundfish limited entry trawl fishery-final environmental impact statement including regulatory flexibility review and initial regulatory flexibility analysis. Pac. Fish. Manage. Counc., Portland, Oreg., 1,583 p.

2013a. Pacific Coast fishery ecosystem plan for the U.S. portion of the California current large marine ecosystem. Pac. Fish. Manage. Counc., Portland, Oreg., 195 p.

2013b. Section 2.2-Protected species regulations. Status of the U.S. west coast fisheries for highly migratory species through 2012. Pac. Fish. Manage. Counc., Portland, Oreg., $78 \mathrm{p}$.

2014a. Pacific Coast groundfish limited entry fixed gear sablefish permit stacking (catch shares) program review. Pac. Fish. Manage. Counc., Portland, Oreg., 8 p. 2014b. Status of the Pacific Coast coastal pelagic species fishery and recommended acceptable biological catches: stock assessment and fishery evaluation 2014. Pac. Fish. Manage. Counc., Portland, Oreg., 340 p. 2016a. Review of 2015 ocean salmon fisheries: assessment and fishery evalua- tion document for the Pacific Coast salmon fishery management plan. Pac. Fish. Manage. Counc., Portland, Oreg., 340 p.

2016b. Status of the U.S. West Coast fisheries for highly migratory species through 2014: stock assessment and fishery evaluation. Pac. Fish. Manage. Counc., Portland, Oreg., 70 p.

Radovich, J. 1982. The collapse of the California sardine fishery-what have we learned? CalCOFI Rep. 23:56-78.

Ralston, S. 2002a. The groundfish crisis - what went wrong? In J. Carless (Editor), Ecosystem observations of the Monterey Bay $\mathrm{Na}$ tional Marine Sanctuary 2002, p. 19-20. Monterey Bay Natl. Mar. Sanct., Monterey, Calif.

2002 b. West coast groundfish harvest policy. N. Am. J. Fish. Manage. 22(1): 249-250. (https://doi.org/10.1577/1548-8675 (2002)022<0249:WCGHP>2.0.CO;2).

Rockland, S. 1978. The San Diego tuna industry and its employment impact on the local economy. Mar. Fish. Rev. 40(7):5-11.

Saarman, E. T., and M. H. Carr. 2013. The California Marine Life Protection Act: a balance of top down and bottom up governance in MPA planning. Mar. Pol. 41:41-49. (https:// doi.org/10.1016/j.marpol.2013.01.004).

Sakagawa, G. 1991. Are U.S. regulations on tuna-dolphin fishing driving U.S. seiners to foreign-flag registry? N. Am. J. Fish. Manage. 11(3):241-252. (https://doi. org/10.1577/1548-8675(1991)011<0241:AU SROT $>2.3 . \mathrm{CO} ; 2$ )

Satterthwaite, W. H., M. S. Mohr, M. R. O'Farrell, E. C. Anderson, M. A. Banks, S. J. Bates, M. R. Bellinger, L. A. Borgerson, E. D. Crandall, J. C. Garza, B. J. Kormos, P. W. Lawson, and M. Palmer-Zwahlen. 2014. Use of genetic stock identification data for comparison of the ocean spatial distribution, size at age, and fishery exposure of an untagged stock and its indicator: California coastal versus Klamath River Chinook salmon. Trans. Am. Fish. Soc. 143(1):117-133. (https://doi org/10.1080/00028487.2013.837096).

Speir, C., C. Pomeroy, and J.G. Sutinen. 2014 Port level fishing dynamics: assessing changes in the distribution of fishing activity over time. Mar. Pol. 46:171-191. (doi: https://doi. org/10.1016/j.marpol.2014.01.014).

Ueber, E., and A. MacCall. 1992. The rise and fall of the California sardine empire. In $\mathrm{M}$. Glantz (Editor), Climate variability, climate change and fisheries, p. 31-48. Cambridge Univ. Press: Cambridge, England

Vojkovich, M. 1998. The California fishery for market squid (loligo opalescens). CalCOFI Rep. 39:55-60.

Wolf, P. 1992. Recovery of the Pacific sardine and the California sardine fishery. CalCOFI Rep. 33:76-86. 